\title{
Model of anthropogenic disturbance impact on the relationships between vegetation and population dynamics of Carex digitata
}

\author{
Grażyna Laska \\ Department of Environmental Protection and Management, Białystok University of Technology, \\ Wiejska 45A St, 15-351 Białystok, Poland, \\ e-mail: g.laska@pb.edu.pl
}

Received: 2 November 2017 / Accepted: 26 January 2018

\begin{abstract}
The aim of the paper is to define a relationship between the diversity in structural features of the Carex digitata population and the dynamics of natural and disturbed anthropogenically oak-hornbeam communities in the cycle of 29-year research (1987-2015) conducted on permanent plots in the Knyszyńska Forest. The results of the research indicate that the population dynamics corresponds significantly to the community dynamics, whereas the existing interrelations are a response of Carex digitata population to dynamic vegetation changes undergoing in natural habitats (fluctuation) and under the influence of anthropogenic disturbances (degeneration as a result of pinetization followed by regeneration). This is reflected in a different spatial organization, age structure, size diversity of individual plants, as well as in various mechanisms regulating the number of individual plants in a population. Models of population dynamics in the light of dynamics of the natural and disturbed forest communities can be explained from the viewpoint of equilibrium and non-equilibrium in the nature. It has been proved that in stable communities, where variations in vegetation have a character of little fluctuations and indicate a state of a relevant equilibrium in the nature, the population of Carex digitata also reaches a phase of relevant equilibrium. In such a phase the size of the sedge population is small and changes in the number of individuals in the 29-year cycle slightly fluctuate. A different variation in the population features has been reported in the anthropogenically disturbed community. Processes of degeneration and regeneration are accompanied by rapid dynamic vegetation changes (a state of non-equilibrium) and rapid changes in structural features of the Carex digitata population. The sedge reaction to the dynamic variations in the communities can be explained by a different life strategy which differentiates morphological and developmental features of individuals and thus determines variation of properties of the population.
\end{abstract}

Key words: Carex digitata, demography, dynamic equilibrium/non-equilibrium of vegetation, long-term study, natural and disturbed communities, plant population.

\section{Introduction}

Dynamics of phytocoenosis, basic units of vegetation, is a manifestation of the dynamics of populations (its components) and changes in the structure and functions of a given population described in a given place and time. At such assumptions, the dynamics of phytocoenosis is estimated by behaviour of populations of the species forming a given phytocoenosis (Jongejans \& Kroon, 2005; Arora et al., 2006; Kalliovirta et al., 2006; Röder \& Kiehl, 2006; Euskirchen et al., 2014; Wullschleger et al., 2014; Song et al., 2015). Significance of the treatment of the hierarchical ecological systems on equal footing with vegetation transformations has been indicated in numerous publications assuming either individual level (the reductionistic approach) or the level of phytocoenoses (holistic approach) (Lavorel \& Garnier, 2002; Shugart, 2003; Garnier et al., 2004; Strong, 2004; Strandberg et al., 2005; Wramneby 
et al., 2008; Corina et al., 2012; Montgomery \& Frelich, 2015). The population research has been considered a core issue for recognition of dynamic processes and rules governing transformations and development of phytocoenoses (Young \& Clarke, 2000; Beissinger \& McCullough, 2002; Bartha et al., 2003; Łaska, 2004; Miyadokoro et al., 2004; Plaza et al., 2012; Gibson et al., 2013). Results of earlier studies have proved that changes in the structure and processes of populations of selected plant species to a large extent can be used as a measure of a degree of deformations of forest communities under the influence of different disturbing factors (Daly et al., 2000; Loehle, 2000; Łaska, 2001; Briggs et al., 2002; Kuuluvainen, 2002; Onaindiaa et al., 2004; Johnson \& Miyanishi, 2007; Lagergren et al., 2012). The influence of anthropogenic disturbances on vegetation communities is significant as it affects a possibility of formation and development of a new cenopopulation of a different life strategy (Westoby et al., 2002; Moles \& Westoby, 2006; Adler et al., 2014; Salguero-Gómez et al., 2016). Changes in the life strategy and modifications in species development in disturbed communities can be an indicator of the level of their disturbance and the ongoing transformations (Łaska, 2012). Therefore, vegetation dynamics and plant populations have become increasingly often subjects to modelling various interrelations in complex systems (Caswell, 2001; Costanza \& Voinov, 2001; Moorcroft et al., 2001; Sykes et al., 2001; Dambacher et al., 2003; Sitch et al., 2003; Hickler et al., 2004; Wehrli et al., 2005; White, 2009; Crone et al., 2011; Lima et al., 2011; Dyakov, 2015). Then, certain laws of dynamics of one species can be treated as models of population functioning in a given ecological system and applied to species with a similar life strategy (Grime, 2001; Iriondo et al., 2003; Geritz \& Gyllenberg, 2005; Grimm \& Railsback, 2005; Parviainen et al., 2008, 2009; Yee \& Mitchell, 2009; Ovaskainen \& Meerson, 2010; Bornhofen et al., 2011).

Vegetation dynamics is a result of direct dynamic-developmental changes in specific communities and populations of plants. As integral components of the specific biocenoses and ecosystems they are subjects to their evolution laws and rules of functioning (Díaz \& Cabido, 2001; Loreau et al., 2001, 2002a; Smith et al., 2001; Eviner \& Chapin, 2003; Daufresne \& Hedin, 2005; Prentice et al., 2006; Fussmann et al., 2007; Zhang et al., 2008; Olabarria et al., 2011; Laughlin et al., 2012; King et al., 2013). The above statement is a main research aim of the 29-year field observations (1987-2015) conducted in natural and disturbed oak-hornbeam anthropogenic communities on the territory of the Knyszyńska Forest. The present paper is an attempt to demonstrate the most significant individual and population interrelations of Carex digitata against a background of the ongoing vegetation transformations. The aim of the demographic analysis is not only to establish the structure and dynamics of the Carex digitata population but mainly to find interrelations between the population dynamics and the dynamics of plant communities in natural and anthropologically disturbed conditions. In the present paper models of community dynamics and plant populations have been determined through vegetation transformations on the level of phytocoenosis and through changing features and properties of the sedge population examined. In this way it has been established how a single population responds to changes in the whole system, to which extent it triggers changes itself, what is the mechanism of the changes and expected further course of variations.

\section{Study site}

The dynamics of vegetation and populations of Carex digitata was studied in natural and disturbed oak-hornbeam communities (Tilio cordatae-Carpinetum betuli Tracz. 1962) on the territory of the Knyszyńska Forest. This is a woodland area of about $1267 \mathrm{~km}^{2}$, located in the NE Poland between lat. 52 ${ }^{\circ} 55^{\prime}$ and $53^{\circ} 42^{\prime} \mathrm{N}$, and long. $22^{\circ} 52^{\prime}$ and $23^{\circ} 54^{\prime}$ E. According to the Kondracki's physico-geographical classification of Poland (2013), it belong to the Podlasie-White Russian Plateau and the eastern part of the North-Podlasie Lowland. In the geobotanic division of Poland it belongs to the Northern Division (Szafer, 1972). Knyszyńska Forest is an old glacial landscape rich in land form shaped by the Warta substage of the Riss glaciation (Kondracki, 2013). Observations were made in natural and secondary forest communities of each particular dynamic vegetation circle (Schwickerath, 1954). Natural and disturbed oak-hornbeam communities presented vegetation developmental series of thawed-out basins, which are associated with flat terrain with a shallow ground water level. It includes communities occurring on clay or silty pseudogley soils (Łaska, 2006). Tilio-Carpinetum physiocenoses occur on low-situated marginal deposits. They are situated in field area between 152.5-155 m above sea level. Natural community with no visible man-induced deformation was taken as model of standard phytocoenosis. Secondary forest community was treated differently, as anthropogenically disturbed by the process of pinetization. In this process 99 years ago the natural oak-hornbeam forest used clear-cutting and artificial reforestation pine (Pinus sylvestris) and now, it is 99-years old secondary forest community with pine stand domination. The study was carried out from 1987 to 2015 (29 years) on two permanent plots of $500 \mathrm{~m}^{2}$ each. The areas under investigation represented typical forms of the above mentioned communities (Laska, 2006). Carex digitata L. (Cyperaceae) is a mesotrophic oak-hornbeam species, growing most often in the natural deciduous and mixed deciduous forests (Matuszkiewicz, 2001; Łaska, 2012) and in the anthropogenically disturbed communities (on the clear-cuts, in pine cultivations, in the 
secondary forest communities with an artificial pine stand) (Hegi, 1964; Łaska, 2006).

\section{Methods}

\subsection{Diversity of communities}

Diversity of the oak-hornbeam natural and anthropogenically disturbed communities was defined using 102 phytosociological records collected in the period $1987-2015$ as a basis. These records were organised into 2 tables of communities (natural and anthropogenically disturbed) and then synthesised in tables of constancy. The present work exhibits results of phytosociological research from 1987 and 2015 with the aim to emphasise the dynamic valour of vegetation. The phytosociological record covered $500 \mathrm{~m}^{2}$ or 5 square of $100 \mathrm{~m}^{2}$ permanent study fields. The BraunBlanquet method, commonly applied in phytosociology, was employed. According to Matuszkiewicz's (2001) a list of characteristics species, categorisation of syntaxonomic groups was performed. The names of vascular plant were given after Mirek et al. (2002) and mosses after Ochyra et al. (2003). The structure of the communities studied was defined. On the basis of an average cover coefficient for each plant layer, Hult's diagram was made to show the vertical structure of the phytocoenoses.

\subsection{Diversity of population}

Assuming that a population structure reflects the response of the ground cover species to changes in the habitat resulting from disturbing factors, the diversity of the population of Carex digitata was defined using as a basis the structural dynamics, age structure, size of individual plants and the dynamics in the number of populations. The material was described by means of field, statistical and graphical methods.

In order to evaluate the spatial structure of populations of Carex digitata, the area of $500 \mathrm{~m}^{2}(10 \times 50 \mathrm{~m})$ was divided into smaller plots $\left(1 \mathrm{~m}^{2}\right)$ and sedge individuals were mapped. A tussock of Carex digitata was established as a basic demographic unit. Plans of tussock distributions were prepared on a scale 1:100. The frequency and density of individuals were evaluated on the basis of the presence and number of individuals in each $1 \mathrm{~m}^{2}$ plot. Thus, on the basis of the prepared maps, and through cartographic and statistical methods, the types of spatial distribution of populations were established, similar to examples given by Chessel (1977). A set of individual plants occurring in neighbouring plots was considered to be an aggregation. Individual plants occurring further than $1 \mathrm{~m}$ from the study plot were included in the next aggregation. On the basis of the above, the density of plants within aggregations, the density of aggregations and their approximate size were established. The evolution of spatial structure was carried out using the Leksis' index. For each population the coefficient of dispersion was evaluated.

During fields observations, life history of tagged individuals in a chosen population was studied and features characterising each individual plant were carefully described. On the basis of morphological and developmental properties the number of individuals in each age stage (juvenile, vegetative, reproductive and senile) was established. This, in turn, provided a basis for the evaluation of the age structure. Also, the measurements of shoot height, the number of elements forming tussock (modules and rosettes) and the stature of tussocks (diameter) were taken. All these elements helped evaluate the size structure of individuals in a population. Numerical data acquired in field observations were processed using package Statistica ver. 13 (StatSoft, Inc., 2017):

- empirical distribution of features - compatibility with the normal distribution was verified through diagrams and the chi-square test;

- mean arithmetical values - standard deviation, confidence intervals on the basis of T-student distribution at significance level $\mathrm{p}=0,05$.

\section{Results}

Models of interrelations between vegetation dynamics and population were determined on the basis of the dynamic changes in natural and disturbed oak-hornbeam communities in the light of variation of features and properties of Carex digitata population growing in different phytocoenoses.

\subsection{Dynamics of vegetation}

Dynamics of vegetation in natural and anthropogenically disturbed oak-hornbeam community in the years 1987-2015 was determined on the basis of florist changes occurring in particular layers of the phytocoenoses studied (Table 1). The research results have proved that in natural oak-hornbeam communities the vegetation changes have a character of fluctuation. In a natural oak-hornbeam stand aged from 101 to 129 , changes mainly consist in physiological death of the older tree individuals (Tilia cordata, Picea abies). They are replaced by a younger generation of the same species or by species of similar ecological requirements (Fraxinus excelsior, Acer platanoides, Carpinus betulus) (Table 1). In the gaps formed after death of individual trees there is an intense growth of underbrush (Corylus avellana) followed by young generation of trees undergrowth (Carpinus betulus), which with the time move to understory layer of the stand. In the herbal layer, in 1987-2015 little 
quantitative changes took place (coverage 74-80\%) which determined different mosaic domination and co-domination of different species (Galeobdolon luteum, Anemone nemorosa, Rubus idaeus). However, most species of the herbal layer in the period of 29 years preserved relevant stability and did not change significantly the area of their presence (Stellaria holostea, Milium effusum, Carex digitata, Oxalis acetosella) (Table 1). The dynamic variations in the oak-hornbeam natural community were of mosaic character and did not cause changes in the community as a whole. They took place on preserving the structure and function of a natural community as well as a character of internal relations with other components of the community and the habitat. The changes resulted in a relevant dynamic equilibrium of vegetation, which secured stability and durability of phytocoenosis and contributed to occurrence of multigenerational and multi-storey natural community. The response to the changes was a relevant dynamic equilibrium of the Carex digitata population.

Other type of dynamic vegetation changes in the cycle of a long-term study (1987-2015) was observed in a disturbed community degenerated by the pinetization process (Table 1). In 1987 the structure of the secondary forest community deformed by the process of pinetization was a medium dense pine stand of 71 years of age. In all lay- ers of this community the pine was accompanied by other coniferous forest species (Picea abies, Vaccinium myrtillus, Pleurozium schreberi) represented similarly as oakhornbeam species. In 1990-2015 rapid dynamic changes of vegetation took place due to anthropogenic activities such as elimination of pine and spruce from the tree layer. As a result of positive selection, deciduous species were preferred in the structure of the community (Carpinus betulus), especially nursed in the undergrowth phase (Carpinus betulus) and underbrush phase (Corylus avellana) (Table 1). The dynamic variations in the secondary forest community pointed to a process of vegetation regeneration, that is reconstruction of the structure and function of the community towards its natural form. In response to the vegetation dynamics rapid changes were observed in the ecological structure of Carex digitata population.

\subsection{Dynamics of plants population of Carex digitata}

The differentiation of population features of Carex digitata was studied in a natural oak-hornbeam community and a community anthropogenically disturbed by the process of pinetization. The observed diversity was determined through study of the spatial organization, age structure, size structure and the dynamics in the number of popu-

Table 1. Floristic diversity of the natural and anthropogenically disturbed communities Tilio-Carpinetum determined on permanent study fields in the period 1987-2015 in the Knyszyńska Forest (Synthetical features: S - Constancy class; Wp - Coefficient of cover)

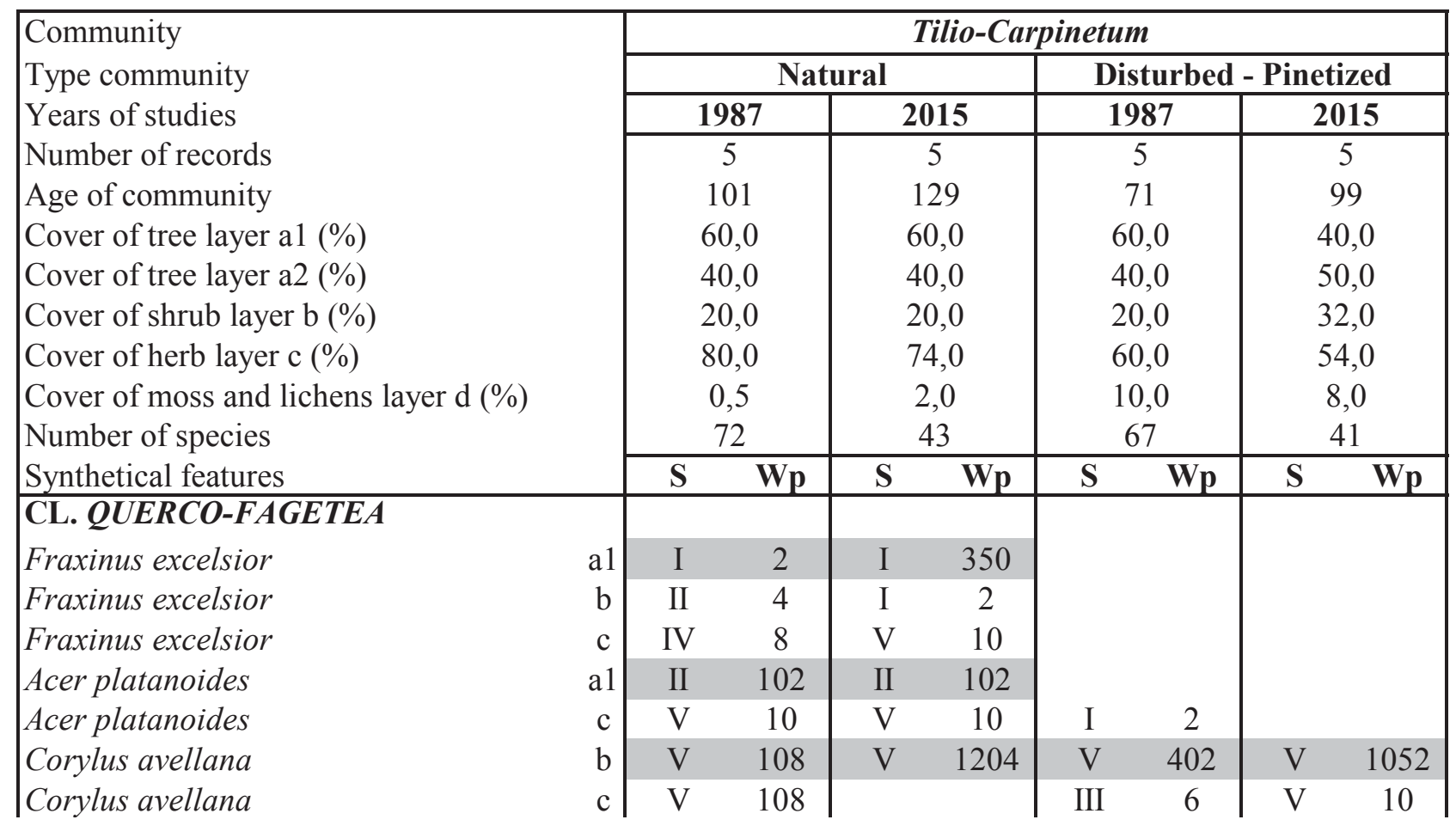




\begin{tabular}{|c|c|c|c|c|c|c|c|c|c|}
\hline Euonymus europaeus & $\mathrm{c}$ & I & 2 & & & I & 2 & & \\
\hline Euonymus verrucosus & $\mathrm{c}$ & I & 2 & & & I & 2 & $\mathrm{~V}$ & 10 \\
\hline Lonicera xylosteum & $\mathrm{c}$ & $\mathrm{I}$ & 2 & & & I & 2 & III & 6 \\
\hline \multirow{2}{*}{$\begin{array}{l}\text { Anemone nemorosa } \\
\text { Hepatica nobilis }\end{array}$} & & V & 206 & $\mathrm{~V}$ & 2700 & IV & 8 & IV & 1052 \\
\hline & & V & 206 & IV & 8 & IV & 704 & III & 104 \\
\hline Carex digitata & & V & 10 & IV & 8 & V & 402 & V & 10 \\
\hline \multirow{4}{*}{$\begin{array}{l}\text { Melica nutans } \\
\text { Aegopodium podagraria } \\
\text { Campanula trachelium } \\
\text { Poa nemoralis }\end{array}$} & & V & 10 & V & 10 & III & 6 & V & 10 \\
\hline & & III & 6 & III & 6 & I & 2 & & \\
\hline & & & & & & I & 2 & & \\
\hline & & I & 2 & & & I & 2 & & \\
\hline \multicolumn{10}{|c|}{ O. FAGETALIA SYLVATICAE } \\
\hline Carpinus betulus & a1 & I & 2 & & & & & & \\
\hline Carpinus betulus & a2 & $\mathrm{V}$ & 750 & V & 1900 & $\mathrm{~V}$ & 1250 & V & 1952 \\
\hline Carpinus betulus & $\mathrm{b}$ & V & 954 & IV & 854 & $\mathrm{~V}$ & 402 & $\mathrm{~V}$ & 1650 \\
\hline Carpinus betulus & $\mathrm{c}$ & V & 10 & $\mathrm{~V}$ & 758 & III & 6 & V & 108 \\
\hline Tilia cordata & a2 & I & 2 & & & & & & \\
\hline Tilia cordata & $\mathrm{c}$ & V & 10 & & & I & 2 & & \\
\hline Daphne mezereum & $\mathrm{c}$ & I & 2 & $\mathrm{~V}$ & 10 & I & 2 & & \\
\hline \multicolumn{2}{|l|}{ Galeobdolon luteum } & V & 1152 & V & 358 & II & 4 & $\mathrm{~V}$ & 10 \\
\hline \multicolumn{2}{|l|}{ Stellaria holostea } & V & 10 & V & 10 & I & 2 & $\mathrm{~V}$ & 10 \\
\hline \multicolumn{2}{|l|}{ Milium effusum } & $\mathrm{V}$ & 10 & $\mathrm{~V}$ & 10 & I & 2 & $\mathrm{~V}$ & 10 \\
\hline \multicolumn{2}{|l|}{ Paris quadrifolia } & IV & 8 & IV & 8 & I & 2 & IV & 8 \\
\hline \multicolumn{2}{|l|}{ Ranunculus lanuginosus } & II & 4 & I & 2 & I & 2 & & \\
\hline \multicolumn{2}{|l|}{ Viola reichenbachiana } & & & $\mathrm{V}$ & 10 & & & $\mathrm{~V}$ & 10 \\
\hline \multicolumn{2}{|l|}{ Pulmonaria obscura } & I & 2 & III & 6 & & & & \\
\hline \multicolumn{2}{|l|}{ Dentaria bulbifera } & IV & 8 & IV & 8 & & & & \\
\hline \multicolumn{2}{|l|}{ Dryopteris filix-mas } & $\mathrm{I}$ & 2 & $\mathrm{~V}$ & 10 & & & & \\
\hline \multicolumn{2}{|l|}{ Galium odoratum } & IV & 8 & $\mathrm{~V}$ & 10 & & & & \\
\hline \multicolumn{2}{|l|}{ Polygonatum multiflorum } & I & 2 & $\mathrm{~V}$ & 10 & & & & \\
\hline \multicolumn{2}{|l|}{ Asarum europaeum } & I & 2 & $\mathrm{~V}$ & 10 & & & & \\
\hline \multicolumn{2}{|l|}{ Lathyrus vernus } & I & 2 & & & & & & \\
\hline \multicolumn{2}{|l|}{ Actaea spicata } & I & 2 & & & & & & \\
\hline \multicolumn{2}{|l|}{ Festuca gigantea } & I & 2 & & & & & & \\
\hline \multicolumn{2}{|l|}{ Phyteuma spicatum } & I & 2 & & & & & & \\
\hline \multicolumn{2}{|l|}{ Scrophularia nodosa } & I & 2 & & & & & & \\
\hline \multicolumn{2}{|l|}{ Stellaria nemorum } & & & $\mathrm{V}$ & 10 & & & & \\
\hline \multicolumn{2}{|l|}{ Lilium martagon } & & & & & II & 4 & & \\
\hline Eurhynchium angustirete & $\mathrm{d}$ & $\mathrm{V}$ & 304 & II & 4 & & & & \\
\hline Atrichum undulatum & $\mathrm{d}$ & $\mathrm{V}$ & 10 & $\mathrm{~V}$ & 10 & & & I & 2 \\
\hline CL. VACCINIO-PICEET & & & & & & & & & \\
\hline Pinus sylvestris & a1 & & & & & $\mathrm{V}$ & 2950 & V & 1052 \\
\hline Pinus sylvestris & a2 & & & & & & & $\mathrm{V}$ & 108 \\
\hline Picea abies & al & V & 750 & III & 300 & $\mathrm{~V}$ & 1250 & $\mathrm{~V}$ & 554 \\
\hline
\end{tabular}




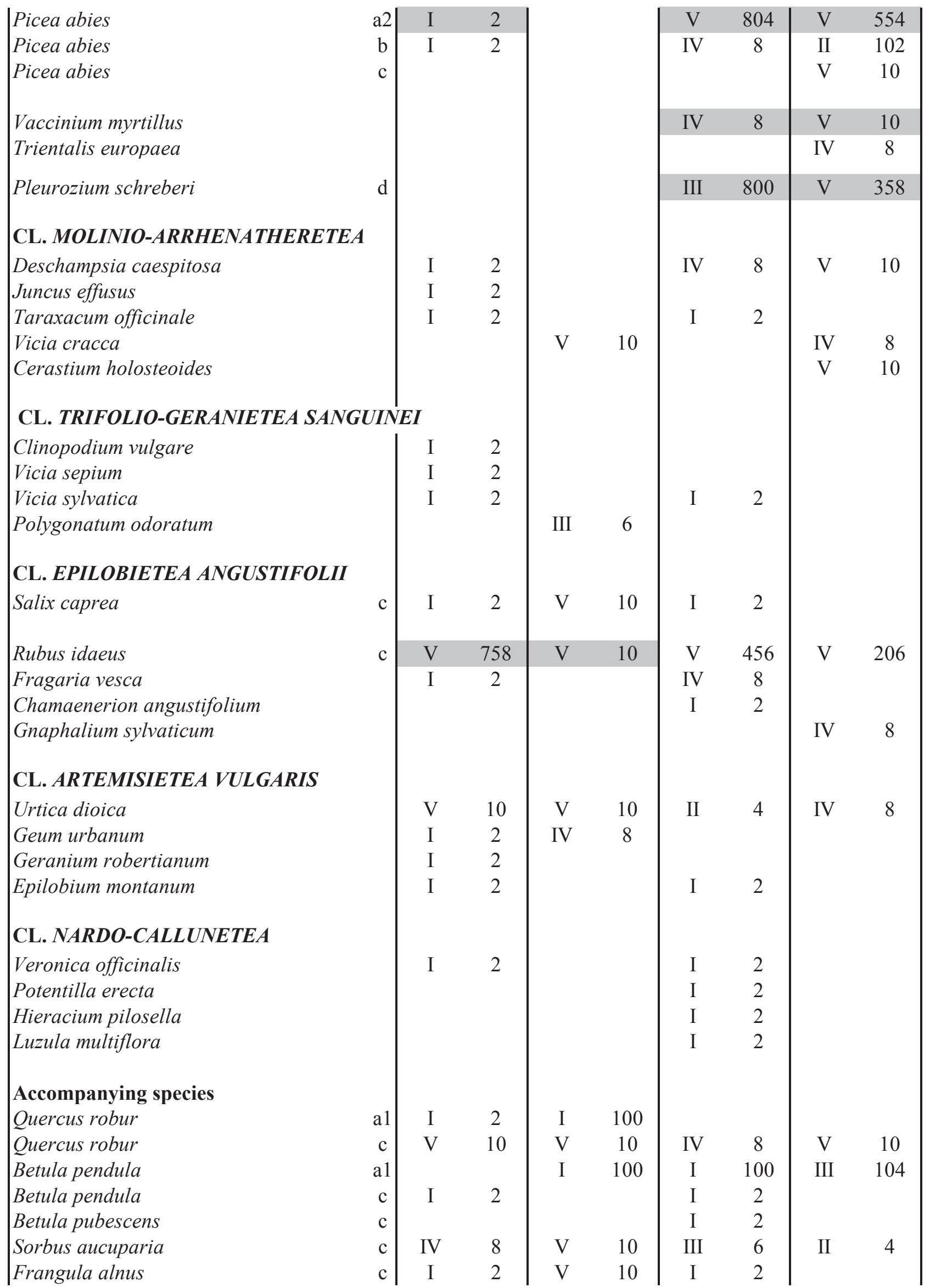




\begin{tabular}{|l} 
Viburnum opulus \\
Malus sylvestris \\
Oxalis acetosella \\
Maianthemum bifolium \\
Dryopteris carthusiana \\
Mycelis muralis \\
Veronica chamaedrys \\
Equisetum sylvaticum \\
Dryopteris dilatata \\
Moehringia trinervia \\
Rubus saxatilis \\
Athyrium filix-femina \\
Luzula pilosa \\
Ajuga reptans \\
Convallaria majalis \\
Hypericum perforatum \\
Galeopsis tetrahit \\
Lapsana communis \\
Carex lasiocarpe \\
Calamagrostis arundinacea \\
Viola mirabilis \\
Gymnocarpium dryopteris \\
Carex pallescens \\
Rumex acetosella \\
Stellaria media \\
Plagiomnium affine \\
Polytrichum commune
\end{tabular}

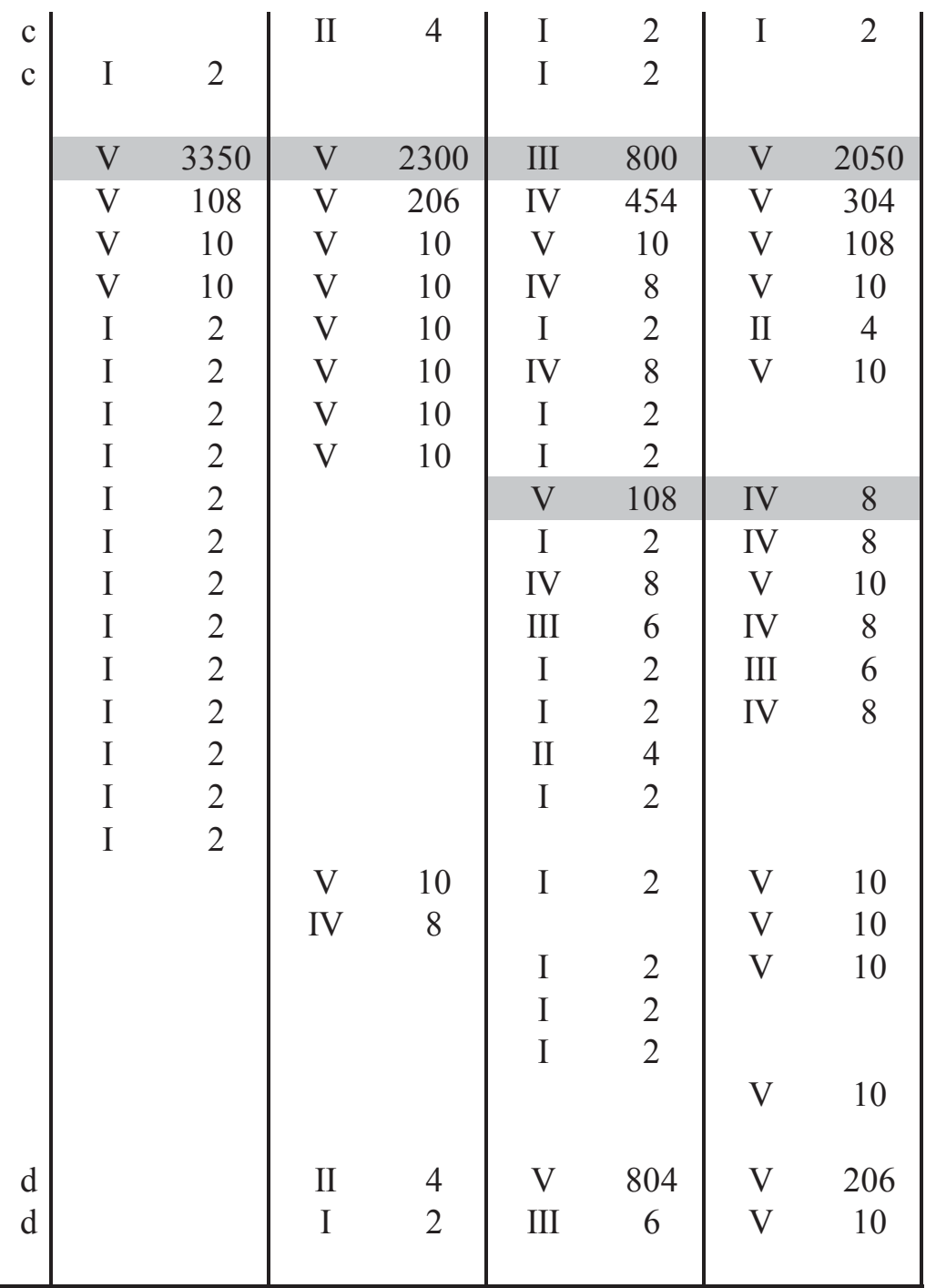

lations and the changes in these features over the period 1987-2015. Populations of Carex digitata in the natural and the anthropogenically disturbed communities differed in size. A larger number of populations and temporal changes were observed in the anthropogenically disturbed community than in the natural oak-hornbeam community.

\subsubsection{Changes in spatial organisation of Carex digitata}

A characteristic feature of the spatial structure of populations in the natural and the anthropogenically disturbed communities is a tendency to aggregate. This observation is confirmed by high values $(>1)$ of dispersion coefficient (Table 2). Dynamic changes in the natural and the disturbed anthropogenic oak-hornbeam communities are responsible for development of considerable differences in the spatial structure of the population studied.

Spatial organisation of populations in the natural oak-hornbeam community was different from that in the anthropogenically disturbed community. Signi- ficant differences were observed in terms of the density of individuals per unit area, within aggregations, the size of aggregations and their distribution in the studied populations (Fig. 1). In the natural oak-hornbeam community, the density of individual plants in the population was low changed slightly over the years 1987-2015 and amounted to about 1 individual per $10 \mathrm{~m}^{2}$. In the natural oak-hornbeam community the number of tussocks in aggregations and the area they covered was low and changed insignificantly in the 29-year research cycle (Table 2). The area of an aggregation ranges on average, from about $2 \mathrm{~m}^{2}$ to $6 \mathrm{~m}^{2}$. The maximum number of individuals in an aggregation was 5 to 27 tussocks, while in the aggregation area of $1 \mathrm{~m}^{2}$ the maximum number of tussocks observed ranged from 4 to 7 . In the natural oak-hornbeam community the aggregations of individual plants were at noticeable distances from one another (Fig. 1a). The type of spatial structure of this population resembles the distribution type described by Chessel (1977) as dispersed-aggregated. 


\begin{tabular}{|c|c|c|c|c|}
\hline & $\mid \frac{m}{3}$ & 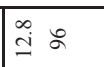 & 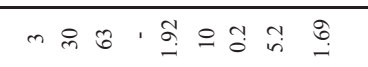 & 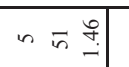 \\
\hline & 产 & $\underline{3}$ & 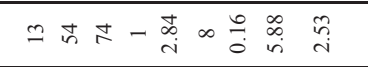 & 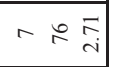 \\
\hline & 䓂 & 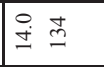 & 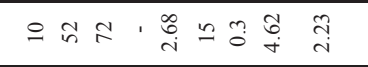 & 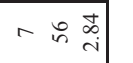 \\
\hline & 玄 & $\dot{\square}$ & $\simeq$ 虽 & 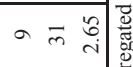 \\
\hline & 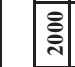 & $\approx 2$ & 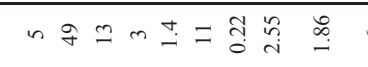 & $0 \subseteq \underset{\mathrm{i}}{\stackrel{t}{4}}$ \\
\hline $\mid$ & \begin{tabular}{|l|l|}
$\infty$ \\
$\vdots$ \\
$\vdots$
\end{tabular} & $+\stackrel{8}{i}$ & 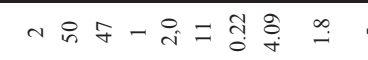 & in $\overrightarrow{i n} \underset{\sim}{\stackrel{\infty}{\sim}}$ \\
\hline : & 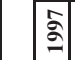 & $\begin{array}{ll}\infty \\
\text { ja }\end{array}$ & , & 的寻穿 \\
\hline 。 & $\sim \vdots$ & $\stackrel{\text { త్ర }}{\circ}$ & m & $n$ 용 \\
\hline $\mid$ & 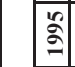 & $\stackrel{+}{=} \approx$ & 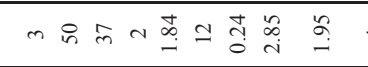 & $+\approx \stackrel{n}{\infty}$ \\
\hline 槒 & 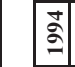 & 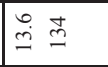 & 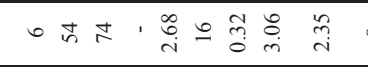 & $\infty \begin{array}{l}4 \\
\infty\end{array}$ \\
\hline & \begin{tabular}{|l|l|l}
2 \\
\end{tabular} & בิ I & 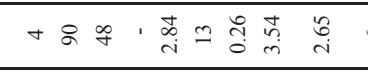 & 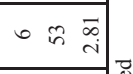 \\
\hline & 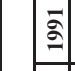 & $\frac{4}{4}+\frac{4}{4}$ & 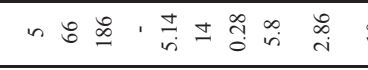 & 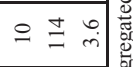 \\
\hline & 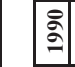 & 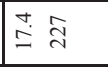 & 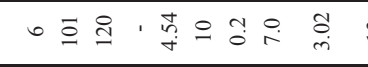 & $\cong \cong 7$ \\
\hline & 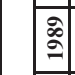 & 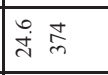 & 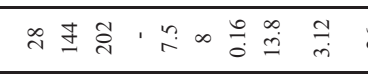 & 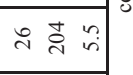 \\
\hline & \begin{tabular}{|l|l}
0 \\
$\substack{0 \\
:}$ \\
\end{tabular} & 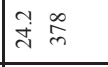 & 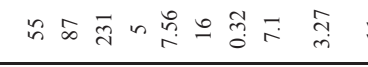 & $=\$ 7$ \\
\hline & 帘 & $\cong$ in & 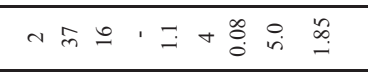 & ナন \\
\hline & क⿳亠े禸 & $\begin{array}{lll}2 & 0 \\
\infty & 8 \\
\end{array}$ & ' & $n \simeq$ \\
\hline & \begin{tabular}{|l|l|}
\multirow{2}{*}{} \\
\end{tabular} & $0_{\infty}$ in & - & $m \sim \stackrel{3}{3}$ \\
\hline & : & 8 的 & 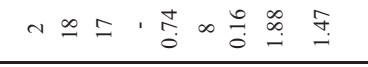 & $m \sim \stackrel{0}{\rightarrow}$ \\
\hline & 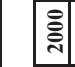 & $\infty$ o & 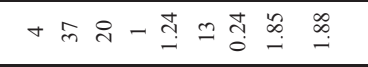 & $0 \cong \stackrel{\vec{i}}{0}$ \\
\hline & \begin{tabular}{|l|l|}
$\infty$ \\
$\vdots$ \\
$\vdots$
\end{tabular} & $\infty \begin{array}{ll}\infty & 0 \\
\infty & 0\end{array}$ & 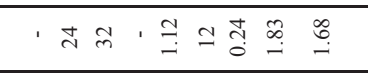 & $\sin \frac{t}{\mathrm{t}}$ \\
\hline & 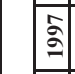 & $\begin{array}{lll}6 & 0 \\
\infty & 0\end{array}$ & 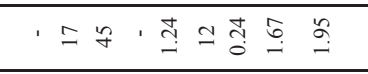 & $+0 \stackrel{0}{0}$ \\
\hline 省 & -2 & $\begin{array}{lll}\infty & 0 \\
& 8\end{array}$ & 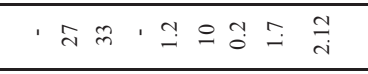 & $n \sim \stackrel{8}{-}$ \\
\hline & \begin{tabular}{|l|l|}
0 \\
2 \\
\end{tabular} & $\underset{i}{i}$ in & ' ন & $+a=$ \\
\hline & \begin{tabular}{|l|l|}
\multirow{2}{2}{} \\
\end{tabular} & $0_{\infty}$ in & 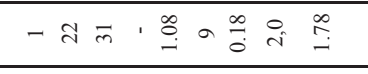 & $+6 \stackrel{0}{-1}$ \\
\hline & \begin{tabular}{|l|l|l}
2 \\
2
\end{tabular} & $\begin{array}{ll}0 \\
0\end{array}$ & 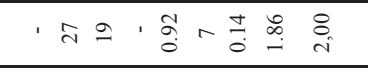 & $+r=$ \\
\hline & \begin{tabular}{|c|c|}
$g$ \\
\end{tabular} & 竞解 & - & $+=9$ \\
\hline & \begin{tabular}{|l|l|l} 
\\
\end{tabular} & fis & - & $+\infty \vec{i}$ \\
\hline & 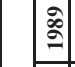 & as of & 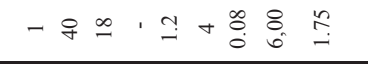 & $n \pi$ \\
\hline & 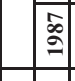 & 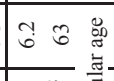 & 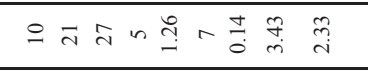 & $\sim \pm \stackrel{\infty}{i}$ \\
\hline 2 & $\frac{0}{0}$ & 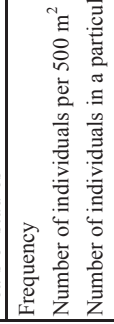 & 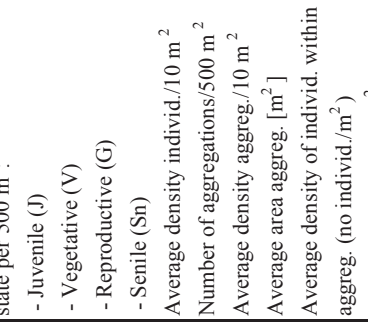 & 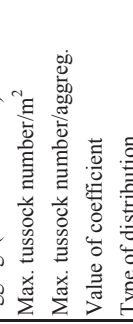 \\
\hline
\end{tabular}


In the anthropogenically disturbed community, the spatial structure of Carex digitata population assumed different properties (Table 2, Fig. 1b). The density of individual plants in the population was high. In 1987-2015 it changed significantly, decreasing rapidly from about 7.6 to 2 individuals per $10 \mathrm{~m}^{2}$. In 1987, the number of tussocks in aggregations and the area they cover were high. In the 29-year of study these values significantly and rapidly decreased (Table 2). The area of an aggregation ranged on average from $7-14 \mathrm{~m}^{2}$ to $2.6-5.9 \mathrm{~m}^{2}$. The maximum number of individuals in an aggregation decreased from 190-204 to 10-76 tussocks, while in the area of $1 \mathrm{~m}^{2}$ of an aggregation the maximum number of tussocks observed decreased from 11-26 to 4-9. Frequency values also show similar interrelations to the variation described (Table 2). In the population studied the variation in the spatial organisation over the years 1987-2015 was found quite significant. The distribution of individuals in space changed from corn-aggregate to dispersed-aggregate (Table 2, Fig. 1b). A change in the spatial organisation in the disturbed community may indicate a regression of the Carex digitata population.

\subsubsection{Age structure of Carex digitata populations}

A life cycle of Carex digitata in the natural oak-hornbeam community lasts from 5 to 10 years. An individual reaches the reproductive phase in the fourth year of life, when the flower shoots appear. It was found that, in the life cycle of plants in the anthropogenically disturbed community, the time required for a plant to reach the reproductive phase was shorter in comparison with that of individual plants in the natural oak-hornbeam community. The reduction was due to shorter duration of other stages - seedling, juvenile and vegetative. In the anthropogenically disturbed community the reproductive stage was reached by plants by the second season of growth. Therefore, the development of the Carex digitata populations in the communities studied revealed a significant variation in the proportions of individual plants at different age stages (Fig. 2). In the years 1987-2015, the following two types of age distribution and their characteristic changes were observed:

1) Domination of individuals in the vegetative stage or, at some stage in development of the population, an increase in the number of individuals in the reproductive stage; the phenomena occurred in the population from the natural oak-hornbeam community.

2) Domination of individuals in the reproductive stage, but rapid changes in proportions of individuals at different age stages took place: an increase in the numbers of individuals in the vegetative stage was accompanied by a decrease in the number of individuals in the reproductive stage; these dynamic changes occurred in the population from the anthropogenically disturbed community.
The variation in the age structure described above in the sedge populations studied was reflected in the shape of the age structure pyramids (Fig. 2). In the population from the natural oak-hornbeam community the age structure appeared graphically as a flat-pyramid (1989, 1990, $1993,2000,2006,2015)$ and an increase in the number of individuals in the vegetative stage was observed (from $59 \%$ to $72 \%$ ) (Fig. $2 a$ ). In the other years from the period studied the age structure of the population assumed graphically the urn-type pyramid $(1995,1996,1998,2003,2009)$ and the proportions of individuals in the reproductive (46$57 \%$ ) and vegetative stages (43-51\%) were similar. In the population from the natural oak-hornbeam community a flat inverted pyramid reflecting a meaningful domination of individuals in the reproductive phase (from $43 \%$ to $73 \%$ ) was found only in the years $1987,1991,1994$ and 1997. In the population from the anthropogenically disturbed community the changes in the age structure pyramids were different than in the natural oak-hornbeam community (Fig. 2b). In the population from anthropogenically disturbed community, the age structure appeared graphically as an inverted pyramid and an increase in the number of individuals in the reproductive stage (from 52\% to $72 \%$ ) was observed. The exceptions were the populations from the years 1993, 1995, and 2000, where the shape was transformed from an inverted pyramid to a flat-pyramid. These dynamic changes reflected the rapid changes in the proportions of individuals in the vegetative stage (from $54 \%$ to $70 \%$ ) (Fig. 2 b).

\subsubsection{Size structure of individuals and temporal changes}

The study revealed statistically significant differences in the heights of individual plants and in the structure of the sedge tussocks in the populations from the natural and the anthropogenically disturbed communities (Fig. 3).

At the beginning of the observations, in 1987, individuals in the population from the anthropogenically disturbed oak-hornbeam community reached bigger sizes of tussocks (average height $-20.0 \mathrm{~cm}$, tussock diameter $-8.8 \mathrm{~cm}$, average number of modules -1.83 ) than those from the natural oak-hornbeam community (average height $-15.1 \mathrm{~cm}$, tussock diameter $-4.3 \mathrm{~cm}$, average number of modules 1.73). It was found that the changes in the height of the individuals and the structure of sedge tussocks in different populations in the years 1987-2015 significantly correlated with the life cycle of individuals and the capability of reaching the reproductive stage. In the population from the natural oak-hornbeam community, the individuals reached the reproductive stage at the age of 4 . After reaching this stage, in the period of the next 4-5 years, they would develop their aboveground organs, increase the height of shoots and multiply the number of modules and rosettes (Fig. 3). The changes were gradual and periodical. In the popula- 
a)

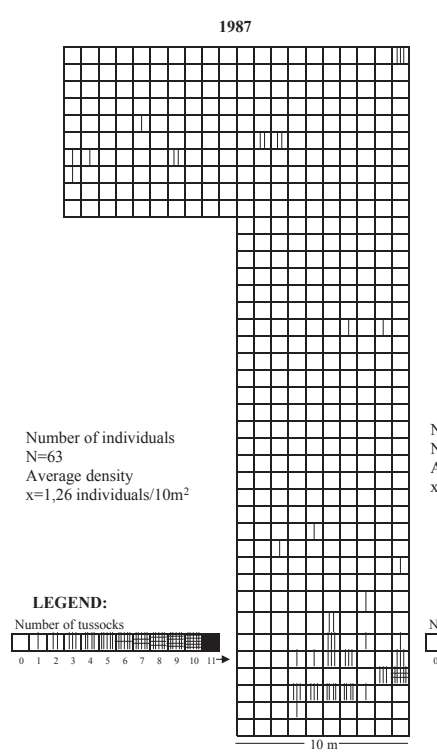

b)
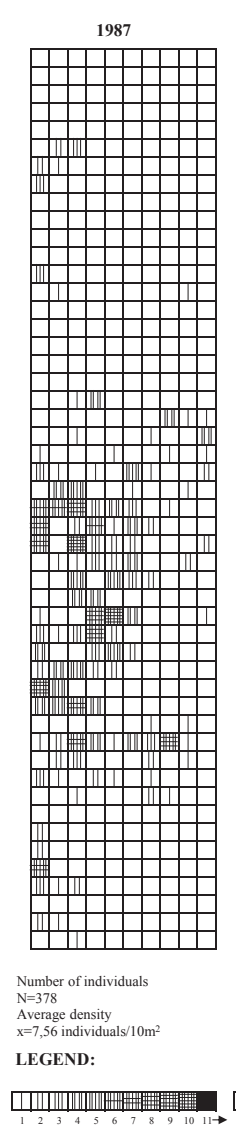

Tilio-Carpin et u m-Natural community
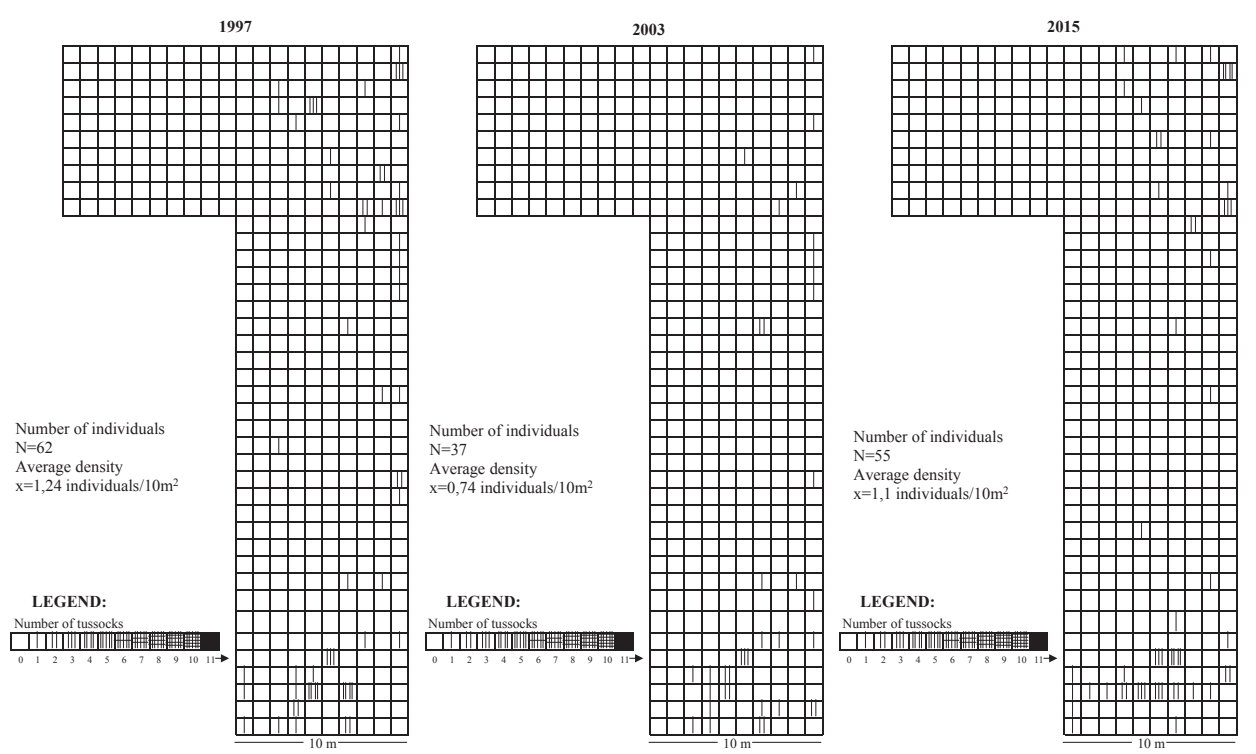

Ti li o-Carpin e t u m - Disturbed community
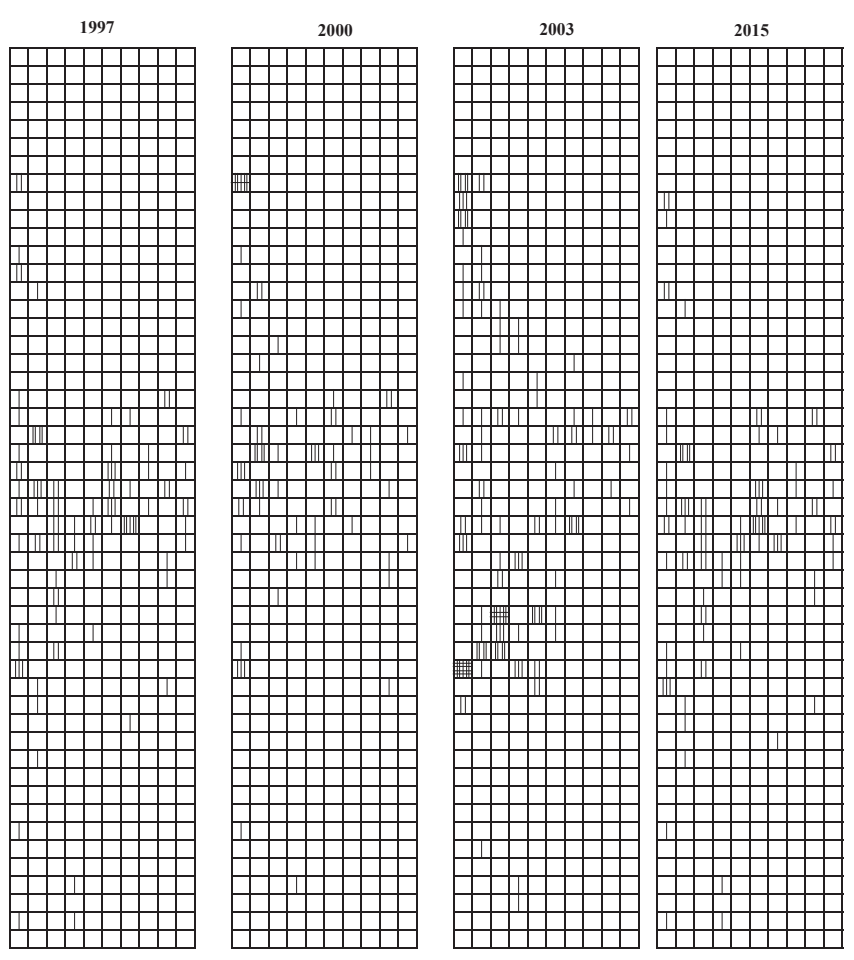

$\underset{\mathrm{N}=97}{\text { Number of individuals }}$

Average density
$\mathrm{x}=1,94$ individuals $10 \mathrm{~m}^{2}$

LEGEND:

$$
\underset{\mathrm{N}=70}{\mathrm{Numb}}
$$

$\underset{\substack{\text { Number of individuals } \\ \mathrm{N}=70}}{\mathrm{~A}=1,4}$

LEGEND:

Number of individual

$\mathrm{N}=131$
Average

$\begin{array}{ll} & \\ \text { LEGEND: } & \mathrm{x}=1,92 \text { individu }\end{array}$

Figure 1. Changes in the spatial structure of Carex digitata populations determined in the period 1987-2015: a) in the natural community, b) in the disturbed community 
a) Tilio-Carpinetum - Natural community
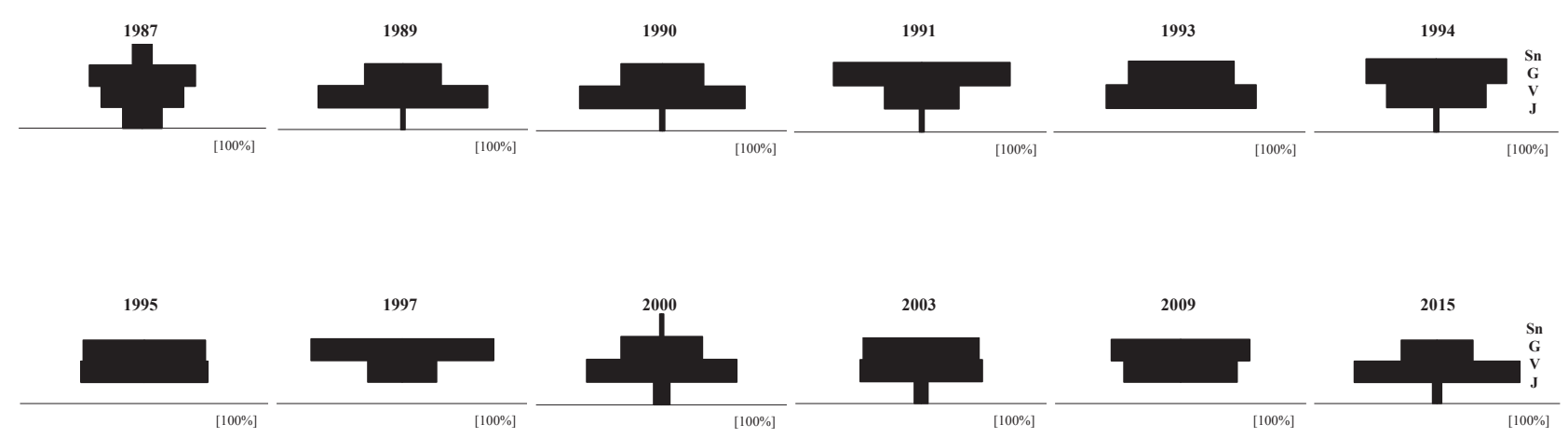

b) Tilio-Carpinetum - Disturbed community
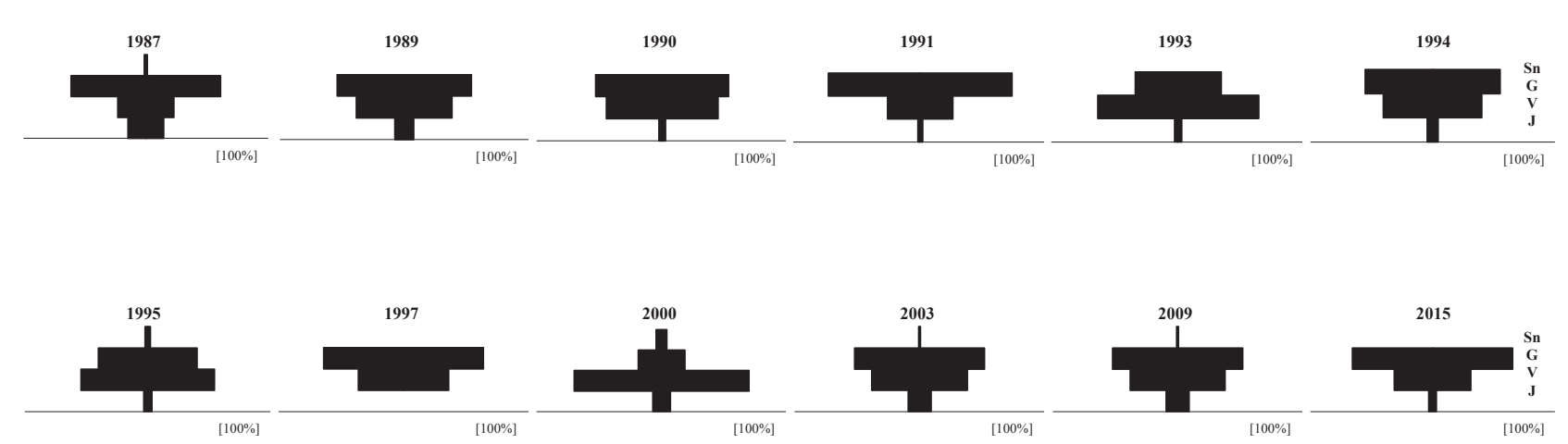

LEGEND:

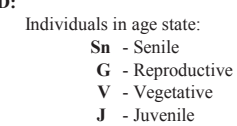

Figure 2. Changes in the age structructure of Carex digitata populations determined in the period 1987-2015: a) in the natural community, b) in the disturbed community

tion from the natural oak-hornbeam community, every 4-5 years an increase in the average height of shoots of the sedge individuals was observed from $15.1 \mathrm{~cm}$ to $24.4 \mathrm{~cm}$ in the years $1987-1991$ and from $17.7 \mathrm{~cm}$ to $22.9 \mathrm{~cm}$ in the years 1993-1998. The height of the individuals in the natural oak-hornbeam community, in the years 1987-2015 increased, however only slightly, their average height from $15.1 \mathrm{~cm}$ to $19.7 \mathrm{~cm}$ (Fig. 3). The maximum height of individual plants reached from 26 to $37 \mathrm{~cm}$. The tussock consisted of a maximum of 3 to 14 modules and 7 to 20 rosettes. In the population from the natural oak-hornbeam community, the most pronounced changes in the structure of the sedge tussocks were reported in 1995-1996, where individuals reached the greatest average number of modules (2.78) and rosettes (5.6). In the natural oak-hornbeam community, in the 29-year research cycle (1987-2015), changes in the number of modules in the structure of sedge tussocks were statistically insignificant (from 1.73 to 1.76 modules in a tussock) and the 1-module individuals were dominant. In 1987-2015, greater changes in the structure of the sedge tussocks and statistically significant differences were reported in the decreasing number of rosettes (from 5.4 to 2.9 rosette in a tussock). This supposedly determined the decrease in the sedge tussock diameter in the period of the study, from $4.3 \mathrm{~cm}$ to $4.0 \mathrm{~cm}$.

In the population from the anthropogenically disturbed community, the individuals reached the reproduction stage earlier, already at 2 years of age. A shortened period of reaching the reproduction stage affected the accumulation of biomass and energy for reproduction in a short time, which implied a different formation of the tussock structure and shoot development. Tussocks grew quickly, produced a large number of living and blooming shoots reaching great height in a short time. They did not multiply the modules and rosettes but increased the number of new shoots in the structure units, which ensures a greater cross-section of the tussocks, increased number of living and reproductive shoots and 
thus efficiency of generative reproduction (Fig. 3). In the population from the anthropogenically disturbed community a maximum height of individual plants reached from 29 to $42 \mathrm{~cm}$. The tussock consisted of the maximum 3 to 12 modules and 5 to 21 rosettes. In the community affected by pinetization, individual plants formed tussock of diameters ranging $7.0-8.8 \mathrm{~cm}$, which is twice as much as those from the natural oak-hornbeam community. In the population from the anthropogenically disturbed community the domination of individuals in the reproductive phase determined a smaller range of variation in the average values of the tussock's features analysed. However, in the 29-year study (1987-2015), changes in the average height of individuals (from $20.02 \mathrm{~cm}$ to $18.52 \mathrm{~cm}$ ), the number of modules (from 1.83 to 1.60 modules in a tussock), and the number rosettes (from 2.82 to 2.30 ) were statistically significant (Fig. 3). It is supposedly related to a rapid decrease in the population abundance in recent years.

\subsubsection{Models of dynamics of population Carex digitata in the light of vegetation dynamics}

Observations of the life histories of tagged individuals in permanent sites indicated changes in the numbers of individuals in the populations over the years 1987-2015 (Table 2). Changes in the number of individuals in a particular age stage were also observed. The results suggest the following pattern of changes in the population abundances in the perennial life cycle of Carex digitata (Figs 4 and 5):
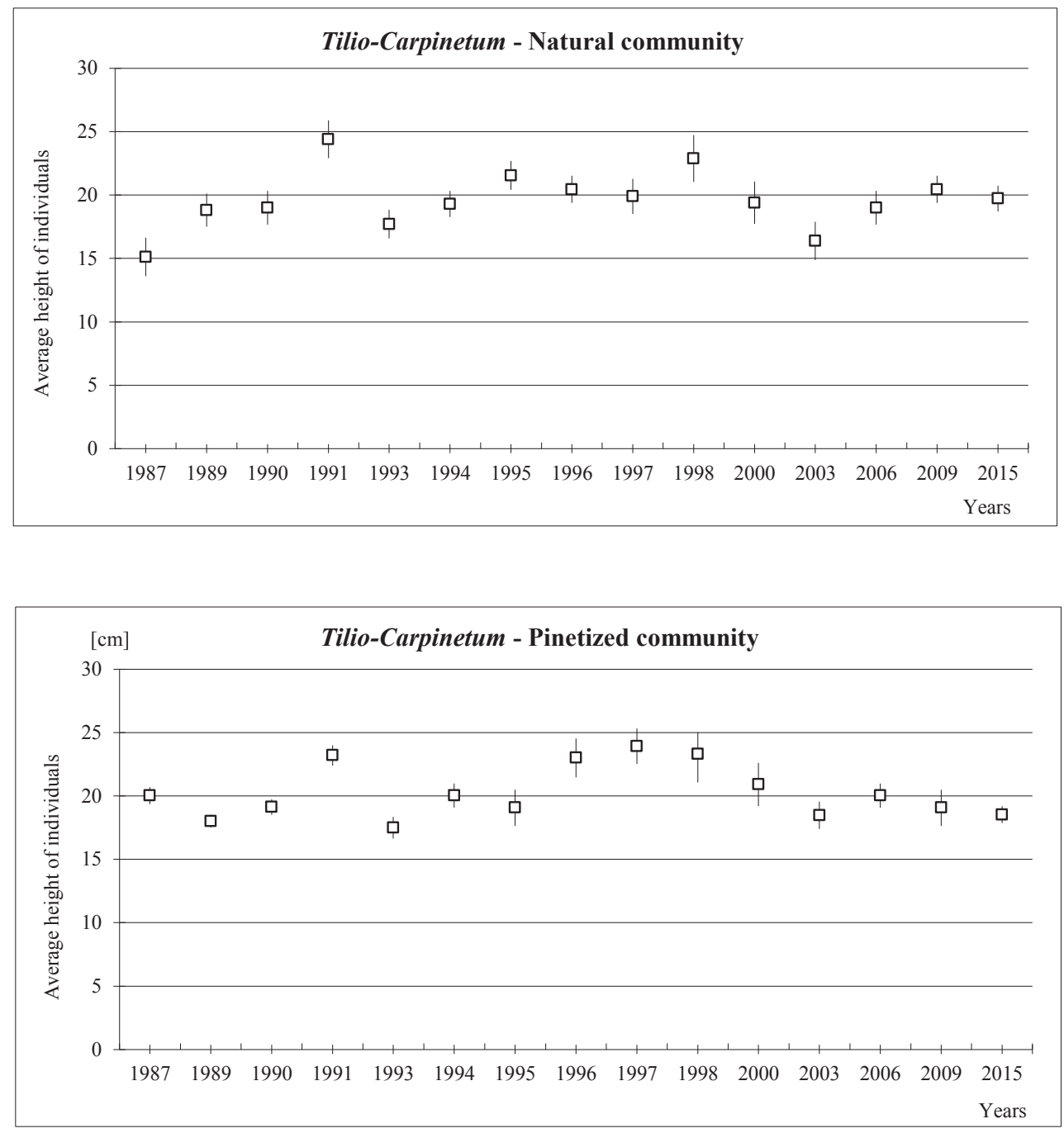

古 $\quad-x \pm L-$ Average height of individuals + confidence limit

Figure 3. Changes in the individuals height of Carex digitata populations determined in the period 1987-2015 in different communities 


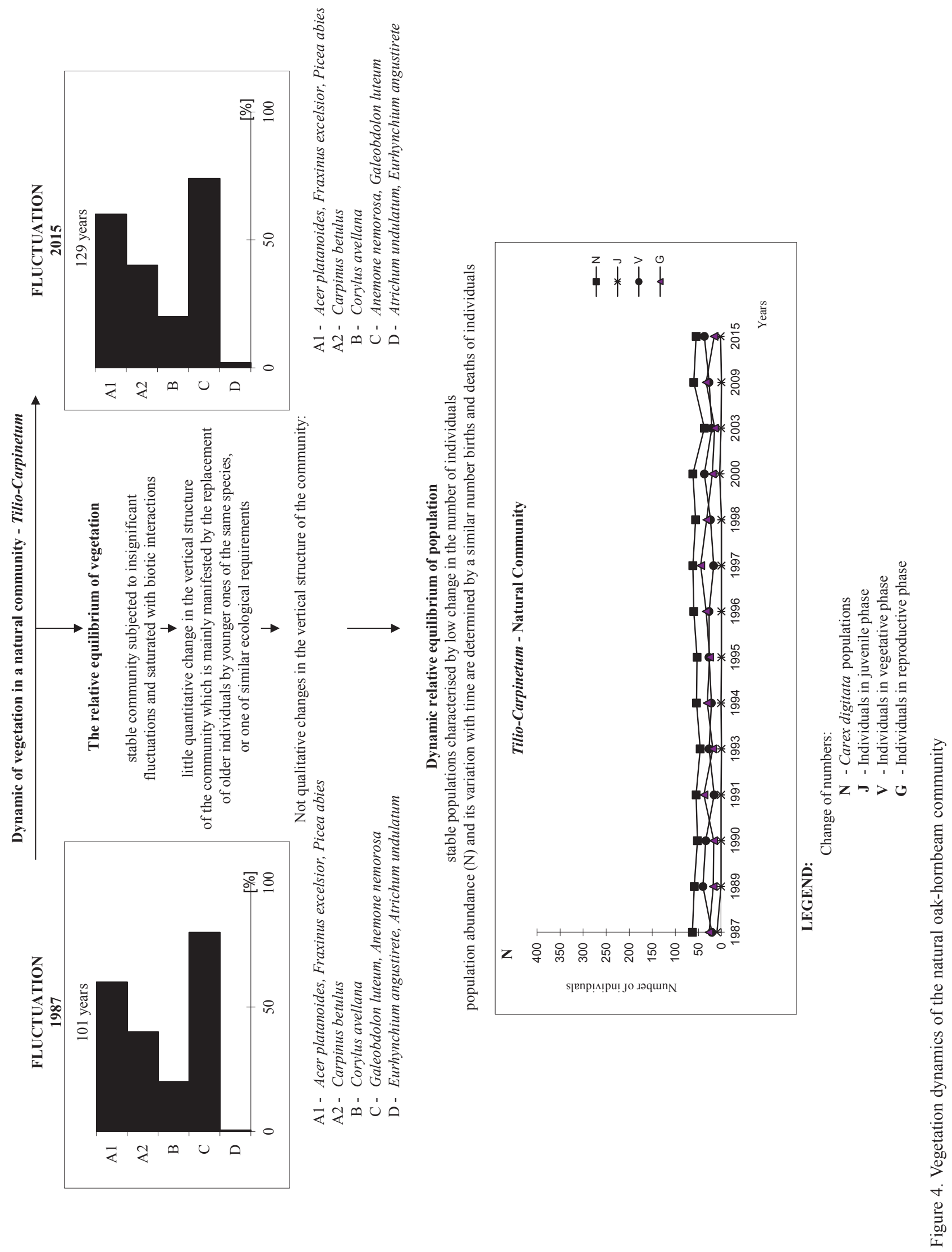




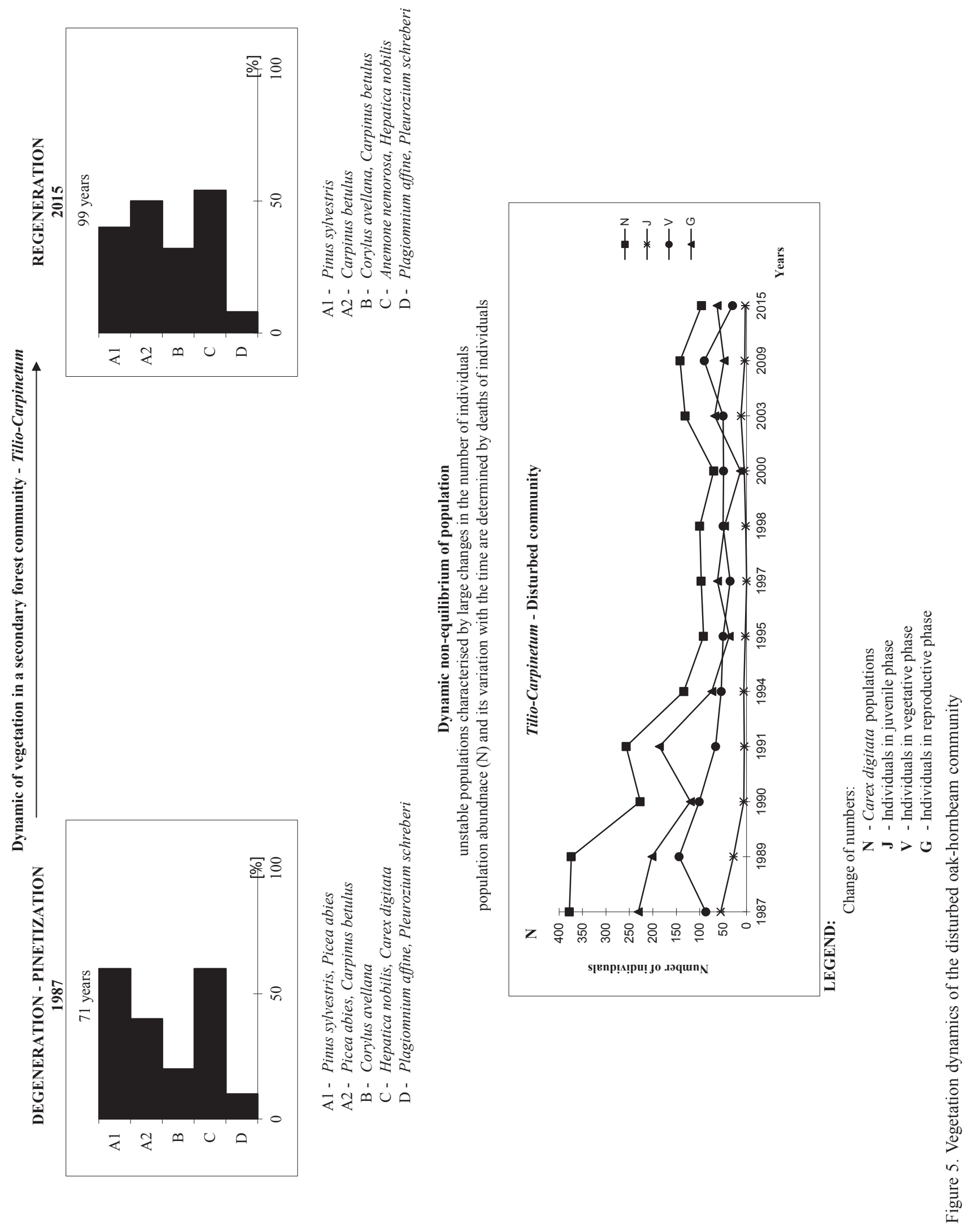


- the numbers of individuals remain at a relatively stable level, or change slightly in the population from the natural oak-hornbeam community;

- in the anthropogenically disturbed community a decline in the population abundance is noted.

At the beginning of the observation period (1987), in an area of $500 \mathrm{~m}^{2}$ a greater number of individual plants in the population was observed in the anthropogenically disturbed (378 individuals) than in the natural oak-hornbeam community (63 individuals) (Table 2). After 29 years, in the natural oak-hornbeam community, the number of populations remained relatively stable. The number of individuals in this population changed, in an oscillatory manner, from 63 to 55 individual plants (Fig. 4). The population in the natural oak-hornbeam community remained relatively constant, as new plants replaced dying ones in a roughly equal number. Dynamics in the Carex digitata population abundance significantly corresponded to the dynamics of vegetation. A relative dynamic equilibrium in the population abundance was a response to the relative stability and durability of the natural oak-hornbeam phytocoenosis (Fig. 4).

After 29 years (1987-2015), the population in the anthropogenically disturbed community declined (from 378 to 96 individuals), as the number of dying plants was higher than that of new plants (Table 2). Changes in the number of individuals may point to a regression of the population studied in the disturbed community due to rapid changes in all layers of phytocoenosis under the effect of anthropogenic activities (Fig. 5).

Different models of the Carex digitata population dynamics correspond to the vegetation dynamics of the natural and disturbed oak-hornbeam communities (Figs 4-5). A specific response of the population to the vegetation transformations enables a determination of directions and intensity of the dynamic processes in these communities.

\section{Discussion and Conclusion}

\subsection{Models of population dynamics and equilibrium and non-equilibrium in vegetation}

The results of the study reported to interrelations between variation in structural features of the population and dynamics of the natural and anthropogenically disturbed communities. Carex digitata response to dynamic changes of the communities can be explained by a different strategy of life, which through differentiation of morphological-developmental properties of individuals determines variation in the population features. This is reflected in different spatial organisation of the population, a different age structure, size structure and other mechanisms regulating the population abundance. Population dynamics significantly corresponds to dynamics of communities and the relations are a response of Carex digitata population to dynamic vegetation changes in the natural habitat (fluctuation) and or imposed by anthropogenic disturbances (degeneration as a result of pinatization followed by regeneration). This implies that they are the response of the sedge population to disturbances of phytocoenotic, microclimatic, habitat factors. Models of population dynamics in the light of dynamics of the natural and disturbed forest communities can be explained assuming the presence of equilibrium and nonequilibrium in nature (Loreau et al., 2002b; Ives \& Carpenter, 2007; Loeuille, 2010; Donohue et al., 2013, 2016; Arnoldi et al., 2016, 2017; Haegeman et al., 2016). In the stabilised communities, where the changes are of fluctuation character, despite the death of individuals (ontogenetically determined), there is a certain state of balance between the level of resources and demands of the species building this community. The relations between the size of gaps and their distribution and the mosaic of the undergrowth and its effective revival are dynamic in character but the inner bounds between the components of the community and its habitat are preserved. It implies the presence of a relative dynamic equilibrium in the natural oakhornbeam community and the phase of relative dynamic equilibrium in the Carex digitata population (Steiner et al., 2006; Stott et al., 2011). In the natural communities, being in the equilibrium phase, the most important from among various factors modifying population properties, according to Grime (2001), is the competition and competitive impact of the other components of a given phytocoenosis. The sedge Carex digitata growing in the conditions of strong competitive pressure of the richly developed ground cover of oak-hornbeam species uses the most biomass and energy for development of vegetative organs (Mustard et al., 2003; Yan et al., 2004; Bornhofen \& Lattaud, 2006). The interspecies competition limits however, the development and growth of progeny and adult individuals (Coomes \& Grubb, 2003; Arora et al., 2006; Bornhofen \& Lattaud, 2009). Therefore, in the natural oak-hornbeam phytocoenosis the number of individuals in the population is low, and so are their changes over the time, the spatial distribution of the population has a character of dispersed-aggregated, and the sedge has little colonisation abilities. There is low density of individuals per unit area and within agglomerations, agglomeration area is small and the number of tussocks in agglomerations is low. Individuals in the vegetative stage dominate in the population. At the beginning of their growth they develop vegetative organs just to survive in the phytocoenosis and when they reach this stage, they are in the vegetative stage to reach the phase of blossoming and fruit bearing at the age of 4 (Laska, 2012). 


\subsection{Phytocoenotic relations and safe germination sites}

Durability of pre-reproductive period may be used as an evaluation criterion to estimate a degree of "competitive pressure" on the sedge individuals from the part of other components of a given phytocoenosis (Howard \& Goldberg, 2001; López et al., 2001; Bornhofen et al., 2011). However, not all individuals of Carex digitata blossom and bear fruit. It has been found that some sedge individuals at the age of 4 do not form reproductive shoots and during subsequent seasons they increase the number of modules and rosettes and the height of shoots. They also develop underground organs (Łaska, 1996a). These are important features of vegetative propagation, however Carex digitata does not reproduce vegetatively but only through seeds (Nowikov, 1967; Fomićeva, 1977). A low number of individuals in the population and its changes over time in the form of small fluctuations and a low efficiency of generative reproduction in the natural oakhornbeam communities can be determined by phytocoenotic relations which restrict the available space and the number of safe germination sites (Schütz, 2000; Baskin $\&$ Baskin, 2001). In the habitat of compact and rich ground cover of the natural oak-hornbeam communities, the number of such safe sites is limited and the covering of the upper layer of soil with permanent underground organs of geophytes and hemicryptophytes leaves little opportunities for the sedge seeds to germinate (Shefferson, 2009). Germination of Carex digitata seeds takes place under the ground (hypogeic mode) (Nowikov, 1967). Therefore, their deposition depth in the soil plays an important role in further development and growth of the individuals. In the oak-hornbeam natural communities, whose changes are fluctuational in character, the most important factor determining a relative dynamic equilibrium of the number of the sedge individuals, type of spatial structure, age structure and size of the individuals in the population is the competition of the other components of the oak-hornbeam ground cover. The competition pressure determines prospective reproduction abilities of the sedge, the size and abundance of the population (Law et al., 2001, 2003, 2009; Begon et al., 2005; Murrell, 2009; Vogt et al., 2010).

Different vegetation dynamic changes were established over the years 1987-2015 in the oak-hornbeam community in the anthropogenically disturbed community. In 1987, in the 71-year-old pine stickstand, in the conditions of extreme habitat stress resulting from degeneration process of natural oak-hornbeam phytocoenosis, the best strategy is to accumulate the maximum biomass and energy for reproduction (Grime, 2001; López et al., 2001; Westoby et al., 2002; Bornhofen \& Lattaud, 2006, 2009; Moles \& Westoby, 2006; Adler et al., 2014; Salguero-Gómez et al., 2016). Individuals reach the reproduction stage ear- ly, and liberation from the pressure of competitors makes Carex digitata to show enormous capabilities of development. In this population, the individuals in the reproductive stage are dominant. The tussocks in a short period of time produce a large number of living and reproductive shoots leading to high reproduction abilities and large population abundance. In the disturbed oak-hornbeam community spatial distribution of the population is of corn-aggregate. There is high density of individuals per $1 \mathrm{~m}^{2}$, high number of agglomerations and high density of individuals in agglomerations. The areas of agglomerations are twice as big than in the natural oak-hornbeam communities.

\subsection{Frequency of the Carex digitata and fertility and acidity of the habitat}

The population abundance and the surface coverage determine a more important role of the sedge in the ground cover of the disturbed oak-hornbeam community that in its natural form (Weiner et al., 2001; Jongejans \& de Kroon, 2005; Stott et al., 2011; Wright et al., 2015). It is related to the fact that frequency of the sedge presence is inversely proportional to the fertility and acidity of the habitat (Yan et al., 2004; Steiner et al., 2006; Gibson et al., 2013). This has also been proved in the earlier studies, where in the most fertile form of eutrophic oak-hornbeam no presence of the sedge has been reported, whereas in the coniferous forest communities the number of individuals in the populations was the highest (2086-2672 individuals per $500 \mathrm{~m}^{2}$ ) (Laska, 1996b). All the data point out that the optimum of Carex digitata occurrence has clearly moved towards more acid soils (up to $\mathrm{pH}$ 4.3-4.5) of the disturbed habitats with planted pines. Pinetization consisting in artificial formation of the forest stand in the place of natural deciduous forests is manifested in the florist changes causing increased participation of acidofile species. In the course of pinetization of oak-hornbeam phytocoenosis, significant changes occur in the soil microflora, kind of litter and the soil $\mathrm{pH}$ into more acidic (Łaska, 2006) as a result of intensive production and fall of conifer needles. Because of these changes, in the disturbed communities the ground cover is poor with a significant contribution of acidofile species, including acidofile moss and the ground litter is different as contains mainly pine needles. These changes in comparison with the natural oak-hornbeam phytocoenosis (considerable richness of the ground cover, deciduous litter which makes it difficult for the seeds to germinate), can also largely determine the size and abundance of the sedge populations in the disturbed oak-hornbeam community. These conclusions have also been confirmed by other authors (Nowikov, 1967; Fomićeva, 1977; Tayler, 2002; 2003; Tayler et al., 2002). They point out that the presence of Carex digitata as a dominator and subdominator is linked to different types of pine and spruce. The range 
of the sedge presence reaches as far as Caucasus and Syberia. Severe and continental climate of Eastern Europe and acidic character of the ground of coniferous forests do not disturb the sedge growth.

\subsection{Dynamic changes of the disturbed oak-hornbeam community towards regeneration of the natural oak- hornbeam community}

In the subsequent years of study, the initiation of the process of regeneration after the anthropogenic disturbances leads to rapid dynamic changes in the vegetation and transformations of the disturbed oak-hornbeam phytocoenosis towards regeneration of the natural oak-hornbeam community. Rapid changes in the vertical structure and the floristic composition of the pine stand towards deciduous stand result in changes in the phytocoenotic (Suding \& Goldberg, 2001; Bisigato \& Bertiller, 2004; Epstein et al., 2012), microclimatic (Cornelissen et al., 2001; King et al., 2013), habitat (Lienert, 2004; Lehsten \& Kleyer, 2007) and phenological conditions (Tayler, 2002, 2003; Tayler et al., 2002). This state implies some kind of inequilibrium in the environment (Shugart, 2003; Hickler et al., 2004; Corina et al., 2012; Euskirchen et al., 2014; Laurent et al., 2017). In response to the vegetation dynamics, the structural features of the Carex digitata population in the disturbed habitat change and with time (in 2015) become similar to their values specified in the sedge population from the natural oak-hornbeam phytocoenosis. In the Carex digitata population in the disturbed oak-hornbeam community there is a significant drop in the number of individuals and a change in spatial distribution from corn-aggregate to dispersed-aggregate. There is also decrease in the number and area of agglomerations, decrease in the frequency and density of individuals per $1 \mathrm{~m}^{2}$. In the age structure of the population serious changes occur in the contribution of individuals in the vegetative and reproductive phases. Also the tussock structure, the height of living shoots, the number of modules and rosettes become similar to those from the natural oak-hornbeam community.

\subsection{Variation in the life history of Carex digitata}

Models of vegetation dynamics and Carex digitata population in the natural and the disturbed oak-hornbeam communities record the transformations taking place in the natural habitat (Sykes et al., 2001; Shugart, 2003; Sitch et al., 2003; Wehrli et al., 2005; Wramneby et al., 2008; Olabarria et al., 2011; Corina et al., 2012; Song et al., 2015). The changes in the populations are both a resultant of demographic process and a response to the dynamic vegetation changes (Young \& Clarke, 2000; López et al., 2001; Moorcroft et al., 2001; Getzin et al., 2008). The rate and intensity of changes in the population properties, and thus in the character of communities are determined mainly by phenotypical variation in the life history traits (Howard \& Goldberg, 2001; Falster \& Westoby, 2003; Bornhofen \& Lattaud, 2006; Gurevitch et al., 2006; Shipley et al., 2006; Adler et al., 2014). Therefore, more often the vegetation dynamics is analysed against a background of demographic processes and the role of species in the formation and disappearance of specific florist compositions is related different life strategies (Grime, 2001; Westoby et al., 2002; Laska, 2004; Fynn et al., 2005; Moles \& Westoby, 2006; Bornhofen et al., 2011; Shefferson et al., 2011; Chadaeva \& Shkhagapsoev, 2016; Salguero-Gómez et al., 2016).

\section{Acknowledgements}

This research was supported by a grant $\mathrm{nr} \mathrm{S} / \mathrm{WBiIS} / 5 / 2016$ from the Ministry of Science and Higher Education of Poland

\section{References}

Adler P.B., Salguero-Gómez R., Compagnoni A., Hsu J.S., Ray-Mukherjee J., Mbeau-Ache C. \& Franco M., 2014, Functional traits explain variation in plant life history strategies. Proceedings of the National Academy of Sciences of the United States of America 111: 740-745.

Arnoldi J.-F., Bideault A., Loreau M. \& Haegeman B., 2017, How ecosystems recover from pulse perturbations: A theory of short- to long-term responses. Journal of Theoretical Biology 436: 79-92.

Arnoldi J.-F., Loreau M. \& Haegeman B., 2016, Resilience, reactivity and variability: a mathematical comparison of ecological stability measures. Journal of Theoretical Biology 389: 47-59.

Arora V., Boer G. \& Arora V., 2006, Simulating competition and coexistence between plant functional types in a dynamic vegetation model. Earth Interactions 10: $1-30$.

Bartha S., Meiners S.J. \& Pickett S.T.A., 2003, Plant colonization windows in a mesic old field succession. Applied Vegetation Science 6: 205-212.

Baskin C.C. \& Baskin J.M., 2001, Seeds. Ecology, Biogeography, and Evolution of Dormancy and Germination. Academic, San Diego, CA.

Begon M., Townsend C.R. \& Harper J.L., 2005, Ecology from individuals to ecosystems, fourth ed. Blackwell Science, Oxford.

Beissinger S.R. \& McCullough D.R., 2002, Population viability analysis. The University of Chicago Press, Chicago. 
Bisigato A.J. \& Bertiller M.B., 2004, Temporal and micro-spatial patterning of seedling establishment. Consequences for patch dynamics in the southern Monte, Argentina. Plant Ecology 174: 235-246.

Bornhofen S., Barot S.\& Lattaud C., 2011, The evolution of CSR life-history strategies in a plant model with explicit physiology and architecture. Ecological Modelling 222: 1-10.

Bornhofen S. \& Lattaud C., 2006, Life history evolution of virtual plants: trading off between growth and reproduction. Lecture Notes in Computer Science 4193: 808-817.

Bornhofen S. \& Lattaud C., 2009, Competition and evolution in virtual plant communities: a new modeling approach. Natural Computing 8: 349-438.

Briggs J.M., Knapp A.K. \& Brock B.L., 2002, Expansion of woody plants in tallgrass prairie: A fifteen-year study of fire and fire-grazing interaction. American Midland Naturalist 147: 287-294.

Caswell H., 2001, Matrix population models: construction, analysis, and interpretation, second ed. Sinauer Associates, Inc., Massachusetts, USA.

Chadaeva V.A. \& Shkhagapsoev S.H., 2016, Theoretical aspects of life strategies of wild plant species. Ekologia Rossii 11: 93-109.

Chessel D., 1977, La description non paramétrique de la dispersion spatiale des individuals d' une espéce. Jurnée franaçaise de biometrie, 28 avril 1977.

Coomes D.A. \& Grubb P.J., 2003, Colonization, tolerance, competition and seed-size variation within functional groups. Trends in Ecology and Evolution 18: 283-291.

Corina M., Bugmann H., Heiri C. \& Wolf A., 2012, Tree mortality in dynamic vegetation models - A key feature for accurately simulating forest properties. Ecological Modelling 24: 101-111.

Cornelissen J.H.C., Callaghan T.V. \& Alatalo J.M., 2001, Global change and arctic ecosystems: is lichen decline a function of increases in vascular plant biomass? Journal of Ecology 89: 984-994.

Costanza R. \& Voinov A.A., 2001, Modeling ecological and economic systems with STELLA: Part III. Ecological Modelling 143: 1-7.

Crone E.E., Menges E.S., Ellis M.E., Knight T.M., Lesica P. \& et al., Bell T., Bierzychudek P., Ehrlén J., Kaye T., Morris W.F., Oostermeijer G., Quintana-Ascencio P.F., Stanley A., Ticktin T., Valverde T. \& Williams J.L., 2011, How do plant ecologists use matrix population models? Ecology Letters 14: 1-8.

Daly C., Bachelet D., Lenihan J.M., Neilson R.P., Parton W. \& Ojima D., 2000, Dynamic simulations of treegrass interactions for global change studies. Ecological Applications 10: 449-469.
Dambacher J.M., Li H.W. \& Rossignol P.A., 2003. Qualitative predictions in model ecosystems. Ecological Modelling 161: 79-93.

Daufresne T. \& Hedin L.O., 2005, Plant coexistence depends on ecosystem nutrient cycles: extension of the resource-ratio theory. Proceedings of the National Academy of Sciences of the United States of America 102: 9212-9217.

Díaz S. \& Cabido M., 2001, Vive la difference: Plant functional diversity matters to ecosystem processes. Trends in Ecology and Evolution 16: 646-655.

Donohue I., Hillebrand H., Montoya J.M., Petchey O.L., Pimm S.L., Fowler M.S., Healy K., Jackson A.L., Lurgi M., McClean D., O'Connor N.E., O’Gorman E.J. \& Yang Q., 2016, Navigating the complexity of ecological stability. Ecology Letters 19: 1172-1185.

Donohue I., Petchey O.L., Montoya J.M., Jackson A.L., McNally L., Viana M., Healy K., Lurgi M., O’Connor N.E. \& Emmerson M.C., 2013, On the dimensionality of ecological stability. Ecology Letters 16: 421-429.

Dyakov N.R., 2015, Rare plants distribution modeling using indirect environmental gradients. Russian Journal of Ecology 46: 332-338.

Epstein H.E., Raynolds M.K., Walker D.A., Bhatt U.S., Tucker C.J. \& Pinzon J.E., 2012, Dynamics of aboveground phytomass of the circumpolar Arctic tundra during the past three decades. Environmental Research Letters 7: 1-12.

Eviner V.T. \& Chapin F.S., 2003, III Functional matrix: A conceptual framework for predicting multiple plant effects on ecosystem processes. Annual Review of Ecology, Evolution, and Systematics 34: 455485.

Euskirchen E.S., Carman T.B. \& Mcguire A.D., 2014, Changes in the structure and function of northern Alaskan ecosystems when considering variable leafout times across groupings of species in a dynamic vegetation model. Global Change Biology 20: 963-978.

Falster D.S. \& Westoby M., 2003, Plant height and evolutionary games, Trends in Ecology and Evolution 18: 337-343.

Fomičeva N.I., 1977, Izmienienije spectra pocek v zavisimosti ot vozrastnovo sostajanija osoki palcatoj. Biologiskije Nauki 4: 97-102.

Fussmann G.F., Loreau M. \& Abrams P.A., 2007, Eco-evolutionary dynamics of communities and ecosystems. Functional Ecology 21: 465-477.

Fynn R.W.S., Morris C.D. \& Kirkman K.P., 2005, Plant strategies and trait trade-offs influence trends in competitive ability along gradients of soil fertility and disturbance. Journal of Ecology 93: 384-395.

Garnier E., Cortez J., Billes G., Navas M-L., Roumet C., Debussche M., Laurent G., Blanchard A., Aubry D., Bellmann A., Neill C. \& Toussaint J.-P., 2004, Plant 
functional markers capture ecosystem properties during secondary succession. Ecology 85: 2630-2637.

Geritz S.A.H. \& Gyllenberg M., 2005, Seven answers from adaptive dynamics. Journal of Evolutionary Biology 18: 1174-1177.

Getzin S., Wiegand T., Wiegand K. \& He F., 2008, Heterogeneity influences spatial patterns and demographics in forest stands. Journal of Ecology 96: 807-820.

Gibson D.J., Baer S.G., Klopf R.P., Reed L.K., Wodika B.R. \& Willand J.E., 2013, Limited effects of dominant species population source on community composition during community assembly. Journal of Vegetation Science 24: 429-440.

Grime J.P., 2001, Plant Strategies, Vegetation processes, and ecosystem properties, second edition. Wiley, N.Y.

Grimm V. \& Railsback S.F., 2005, Individual-based modeling and ecology. Princeton University Press, Princeton.

Gurevitch J., Scheiner S.M. \& Fox G.A., 2006, The ecology of plants. Sinauer Associates, Massachusetts, USA.

Haegeman B., Arnoldi J.-F., Wang S., de Mazancourt C., Montoya J.M. \& Loreau M., 2016, Resilience, invariability, and ecological stability across levels of organization. BioRxiv 085852.

Hegi G., 1964, Illustriete Flora von Mittel-Europa IV.3. Carl Hanser Verlag, München.

Hickler T., Smith B., Sykes M.T., Davis M.B., Sugita S. \& Walker K., 2004, Using a generalized vegetation model to simulate vegetation dynamics in northeastern USA. Ecology 85: 519-530.

Howard T.G. \& Goldberg D.E., 2001, Competitive response hierarchies for germination, growth, and survival and their influence on abundance. Ecology 82: 979-990.

Iriondo J.M., Albert M.J. \& Escudero A., 2003, Structural equation modelling: An alternative for assessing causal relationships in threatened plant populations. Biological Conservation 113: 367-377.

Ives A.R. \& Carpenter S.R., 2007, Stability and diversity of ecosystems. Science 317: 58-62.

Johnson E.A. \& Miyanishi K., 2007, Plant disturbance ecology. Academic Press, San Diego, US.

Jongejans E. \& de Kroon H., 2005, Space versus time variation in the population dynamics of three co-occurring perennial herbs. Journal of Ecology 93: 681-692.

Kalliovirta M., Ryttari T. \& Heikkinen R.K., 2006, Population structure of a threatened plant, Pulsatilla patens, in boreal forests: modelling relationships to overgrowth and site closure. Biodiversity and Conservation 15: 3095-3108.

King D.A., Bachelet D.M \& Symstad A.J., 2013, Climate change and fire effects on a prairie - woodland ecotone: projecting species range shifts with a dynamic global vegetation model. Ecological Evolution 3: 5076-5097.
Kondracki J., 2013, Geografia regionalna Polski [Regional geography of Poland]. PWN, Warszawa.

Kuuluvainen T., 2002, Disturbance dynamics in boreal forests: Defining the ecological basis of restoration and management of biodiversity. Silva Fennica 36: 5-12.

Lagergren F., Jönsson A.M., Blennow K. \& Smith B., 2012, Implementing storm damage in a dynamic vegetation model for regional applications in Sweden. Ecological Modelling 247: 71-82.

Lavorel S. \& Garnier E., 2002, Predicting changes in community composition and ecosystem functioning from plant traits: Revisiting the Holy Grail. Functional Ecology 16: 545-556.

Laughlin D.C., Joshi C., van Bodegom P.M., Bastow Z.A. \& Fulé P.Z., 2012, A predictive model of community assembly that incorporates intraspecific trait variation. Ecology Letter 15: 1291-1299.

Laurent L., Mårell A., Korboulewsky N., Saïd S. \& Balandier P., 2017, How does disturbance affect the intensity and importance of plant competition along resource gradients? Forest Ecology and Management 391: 239245.

Law R., Illian J., Burslem D.F.R.P., Gratzer G., Gunatilleke C. \& Gunatilleke I., 2009, Ecological information from spatial patterns of plants: insights from point process theory. Journal of Ecology 97: 616-628.

Law R., Murrell D.J. \& Dieckmann U., 2003, Population growth in space and time: spatial logistic equations. Ecology 84: 252-262.

Law R., Purves D.W., Murrell D.J. \& Dieckman U., 2001, Causes and effects of small-scale spatial structure in plant populations, [in:] Integrating ecology and evolution in a spatial context, J. Silvertown \& J. Antonovics (eds). Blackwell Science, Oxford: 21-44.

Lehsten V. \& Kleyer M., 2007, Turnover of plant trait hierarchies in simulated community assembly in response to fertility and disturbance. Ecological Modelling 203: 270-278.

Lienert J., 2004, Habitat fragmentation effects on fitness of plant populations - a review. Journal for Nature Conservation 12: 53-72.

Lima L., Zelaya K., Laterra P., Massone H. \& Maceira N., 2011, A dynamic simulation model of land cover in the Dulce Creek Basin, Argentina. Procedia Environmental Sciences 7: 194-199.

Loehle C., 2000, Strategy space and the disturbance spectrum: a life-history model for tree species co-existence. The American Naturalist 156: 14-33.

Loeuille N., 2010, Influence of evolution on the stability of ecological communities. Ecology Letters 13: 15361545.

López F., Fungairiňo S., De las Heras P., Serrano J. \& Acosta F., 2001, Age changes in the vegetative vs. 
reproductive allocation by module demographic strategies in a perennial plant. Plant Ecology 157: 13-21.

Loreau M., Naeem S. \& Inchausti P., 2002a, Biodiversity and ecosystem functioning: synthesis and perspectives. Oxford University Press, Oxford.

Loreau M., Downing A., Emmerson M., Gonzales A., Hughes J., Inchausti P., Joshi J., Norberg J. \& Sala O., 2002b, A new look at the relationships between diversity and stability, [in:] M. Loreau, S. Naeem \& P. Inchausti (eds), Biodiversity and ecosystem functioning: synthesis and perspectives. Oxford University Press, Oxford: 79-91.

Loreau M., Naeem S., Inchausti P., Bengtsson J., Grime J.P., Hector A., Hooper D.U, Huston M.A, Raffaelli D., Schmid B. Tilman D. \& Wardle D.A., 2001, Biodiversity and ecosystem functioning: current knowledge and future challenges. Science 294: 804-808.

Łaska G., 1996a, Changes in the life history of Carex digitata in disturbet woodland communities. I. Life history. Fragmenta Floristica et Geobotanica 41: 419-445.

Łaska G., 1996b, Changes in the life history of Carex digitata in disturbet woodland communities. II. Demography of Carex digitata. Fragmenta Floristica et Geobotanica 41: 447-473.

Łaska G., 2001, The disturbance and vegetation dynamics: a review and an alternative framework. Plant Ecology 157: 77-99.

Łaska G., 2004, Colonisation strategies of species and their ability to colonise disturbed habitats. Ecological Questions 4: 31-45.

Łaska G., 2006, Tendencje dynamiczne zbiorowisk zastępczych w Puszczy Knyszyńskiej [Dynamic tendencies of the secondary communities in the Knyszyńska Forest]. Bogucki Wydawnictwo Naukowe, BiałystokPoznań.

Łaska G., 2012, Changes of the life strategy and adaptation of the reproductive strategy of Carex digitata to disturbances factors. Ecological Questions 16: 9-21.

Matuszkiewicz W., 2001, Przewodnik do oznaczania zbiorowisk roślinnych Polski [Guide to identification of plant communities in Poland]. Wydawnictwo PWN, Warszawa.

Mirek Z., Piękoś-Mirkowa H., Zając A. \& Zając M., 2002, Flowering Plants and Pteridophytes of Poland. A Checklist. W. Szafer Institute of Botany, Polish Academy of Sciences, Kraków.

Miyadokoro T., Nishimura N., Hoshino D. \& Yamamoto S., 2004, Dynamics of forest canopy and major tree populations over nine years in a subalpine old-growth coniferous forest, central Japan. Ecoscience 11: 130136.

Moles A.T. \& Westoby M., 2006, Seed size and plant strategy across the whole life cycle. Oikos 113: 91-105.
Montgomery R. \& Frelich L.E., 2015, Forest succession and gap dynamics, [in:] K. Peh, R. Corlett \& Y. Bergeron (eds), Handbook of forest ecology. Routledge Press, Oxford, UK: 141-153.

Moorcroft P., Hurtt G. \& Pacala S.W., 2001. A method for scaling vegetation dynamics: the ecosystem demography model (ED). Ecological Monography 71: 557-586.

Murrell D.J., 2009, On the emergent spatial structure of size-structured populations: when does self-thinning lead to a reduction in clustering. Journal of Ecology 97: 256-266.

Mustard M., Standing D., Aitkenhead M., Robinson D. \& Mc-Donald A., 2003, The emergence of primary strategies in evolving plant populations. Evolutionary Ecology Research 5: 1067-1081.

Nowikov W.S., 1967, Rod Carex L. vo florie Moskovskoj obłasti (voprosy biomorfołogii, anatomii, systiematiki i gieografii). Nauka, Moskwa.

Ochyra R., Żarnowiec J. \& Bednarek-Ochyra H., 2003, Census catalogue of Polish mosses. W. Szafer Institute of Botany, Polish Academy of Sciences, Kraków.

Olabarria J., Lasch P., Meredieu C., Moreira F., Schelhaas M.J. \& Mohren F., 2011, Modelling natural disturbances in forest ecosystems: a review. Ecological Modelling 222: 903-924.

Onaindiaa M., Domingueza I., Albizub I., Garbisub C. \& Amezagaa I., 2004, Vegetation diversity and vertical structure as indicators of forest disturbance. Forest Ecology and Management 195: 341-354.

Ovaskainen O. \& Meerson B., 2010, Stochastic models of population extinction, Trends in Ecology and Evolution 25: 643-652.

Parviainen M., Luoto M. \& Heikkinen R.K., 2009, The role of local and landscape level productivity in modelling of boreal plant species richness. Ecological Modelling 220: 2690-2701.

Parviainen M., Luoto M., Ryttäri T. \& Heikkinen R.K., 2008, Modelling the occurrence of threatened plant species in taiga landscapes: methodological and ecological perspectives. Journal of Biogeography 35: 1888-1905.

Plaza H.E., Navarrete L., Lacasta C. \& González-Andújar J.L., 2012, Fluctuations in plant populations: role of exogenous and endogenous factors. Journal of Vegetation Science 23: 640-646.

Prentice I.C., Bondeau A., Cramer W., Harrison S.P., Hickler T., Lucht W., Sitch S., Smith B. \& Sykes M.T., 2006, Dynamic global vegetation modeling. Quantifying terrestrial ecosystem responses to large-scale environmental change, [in:] J.G. Canadell, D. Pataki, L.F. Pitelka (eds), Terrestrial Ecosystems in a Changing World. Springer Verlag, Berlin: 175-192.

Röder D. \& Kiehl K., 2006, Population structure and population dynamic of Pulsatilla patens (L.) Mill. in relation to vegetation characteristics. Flora 201: 499-507. 
Salguero-Gómez R., Jones O.R., Jongejans E., Blomberg S., Hodgson D., Zuidema P.A., Kroon de H. \& Buckley Y.M., 2016, Fast-slow continuum and reproductive strategies structure plant life-history variation worldwide. Proceedings of the National Academy of Sciences of the United States of America, 113: 230235.

Schütz W., 2000, Ecology of seed dormancy and germination in sedges (Carex). Perspectives in Plant Ecology Evolution Systematics 3: 67-89.

Schwickerath M., 1954, Die Landschaft und ihre Wandlung auf geobotanischer Grundlage entwickelt und erläuter im Bereich des Messtichblattes Stolberg. Aachen.

Shefferson R.P., 2009, The evolutionary ecology of vegetative dormancy in mature herbaceous perennial plants. Journal of Ecology 97: 1000-1009.

Shefferson R.P., Mccormick M.K., Whigham D.F. \& O’Neill J.P., 2011, Life history strategy in herbaceous perennials: inferring demographic patterns from the aboveground dynamics of a primarily subterranean, myco-heterotrophic orchid. Oikos 120: 1291-1300.

Shipley B., Vile D. \& Garnier É., 2006, From plant traits to plant communities: a statistical mechanistic approach to biodiversity. Science 314: 812-814.

Shugart H.H., 2003, A theory of forest dynamics. The ecological implications of forest succession models. The Blackburn Press, Caldwell, NJ.

Sitch S., Smith B., Prentice I.C., Arneth A., Bondeau A. \& et al., 2003, Evaluation of ecosystem dynamics, plant geography and terrestrial carbon cycling in the LPJ dynamical global vegetation model. Global Change Biology 9: 161-185.

Smith B., Prentice I.C. \& Sykes M.T., 2001. Representation of vegetation dynamics in the modelling of terrestrial ecosystems: comparing two contrasting approaches within European climate space. Global Ecology and Biogeography 10: 621-637.

Song G., Yu M., Liu S. \& Zhang S., 2015, A dynamic model for population mapping: a methodology integrating a Monte Carlo simulation with vegetation-adjusted night-time light images. International Journal of Remote Sensing 36: 4054-4068.

StatSoft, Inc., 2017, Statistica, Data Analysis Software System, Version 13. StatSoft, Inc., Tulsa.

Steiner C., Long Z., Krumins J. \& Morin P., 2006, Population and community resilience in multitrophic communities. Ecology 87: 996-1007.

Stott I., Townley S. \& Hodgson D.J., 2011, A framework for studying transient dynamics of population projection matrix models. Ecology Letters 14: 959-970.

Strandberg B., Kristiansen S.M. \& Tybirk K., 2005, Dynamic oak-scrub to forest succession: Effects of management on understorey vegetation, humus forms and soils. Forest Ecology and Management 211: 318-328.
Strong W.L, 2004, Secondary vegetation and floristic succession within a boreal aspen (Populus tremuloides Michx.) clearcut. Canadian Journal of Botany 82: 15761585.

Suding K.N. \& Goldberg D.E., 2001, Do disturbances alter competitive hierarchies? Mechanisms of change following gap creation. Ecology 82: 2133-2149.

Sykes M.T., Prentice I.C., Smith B., Cramer W. \& Venevsky S., 2001, An introduction to the European terrestrial ecosystem modelling activity. Global Ecology and Biogeography 10: 581-593.

Szafer W., 1972, Podstawy geobotanicznego podziału Polski [The geobotanical division basics of Poland], [in:] W. Szafer \& K. Zarzycki (eds), Szata roślinna Polski, T. 2 [Vegetation of Poland, Vol. 2]. PWN, Warszawa: 9-15.

Tayler T., 2002, Geographic distribution of allozyme variation in relation to post-glacial history in Carex digitata, a widespread European woodland sedge. Journal of Biogeography 29: 9191-9930.

Tayler T., 2003, Allozyme variation in Carex sect. Digitatae - Evidence of introgression, genetic distinctiveness and evolution of taxa. Plant Systematics and Evolution 237: 219-231.

Tayler T., Prentice H.C. \& Widén B., 2002, Geographic variation and dispersal history in Fennoscandian populations of two forest herbs. Plant Systematics and Evolution 233: 47-64.

Vogt D.R., Murrell D.J. \& Stoll P., 2010, Testing spatial theories of plant coexistence: no consistent differences in intra- and interspecific interaction distance. The American Naturalist 175: 73-84.

Wehrli A., Zingg A., Bugmann H. \& Huth A., 2005, Using a forest patch model to predict the dynamics of stand structure in Swiss mountain forests. Forest Ecology and Management 205: 149-167.

Weiner J., Stoll P., Muller-Landau H. \& Jasentuliyana A., 2001, The effects of density, spatial pattern, and competitive symmetry on size variation in simulated plant populations. The American Naturalist 158: 438-450.

Westoby M., Falster D., Moles A., Vesk P. \& Wright I., 2002, Plant ecological strategies: Some leading dimensions of variation between species. Annual Review of Ecology and Systematics 33: 125-159.

White J.-S.S., 2009, Generalized linear mixed models: A practical guide for ecology and evolution. Trends in Ecology and Evolution 24: 127-135.

Wramneby A., Smith B., Zaehle S. \& Sykes M.T., 2008, Parameter uncertainties in the modelling of vegetation dynamics-effects on tree community structure and ecosystem functioning in European forest biomes. Ecological Modelling 216: 277-290.

Wright A.J., Ebeling A., de Kroon H., Roscher C., Weigelt A. \& et al., 2015, Flooding disturbances increase re- 
source availability and productivity but reduce stability in diverse plant communities. Nature Communications 6: 6092. [DOI: 10.1038/ncomms7092].

Wullschleger S.D., Epstein H.E., Box E.O., Euskirchen E.S., Goswami S.I. \& et al., 2014, Plant functional types in Earth system models: past experiences and future directions for application of dynamic vegetation models in high-latitude ecosystems. Annals of Botany 114: 1-16.

Yan H.-P., Kang M.Z., De Reffye P. \& Dingkuhn M., 2004, A dynamics, architectural plant model simulat- ing resource-dependent growth. Annals of Botany 93: 591-602.

Yee T.W. \& Mitchell N.D., 2009, Generalized additivemodels in plant ecology. Journal of Vegetation Science 2: 587-602.

Young A.G. \& Clarke G.M., 2000, Genetics, demography and viability of fragmented populations. Cambridge University Press, Cambridge.

Zhang Z., Liang C. \& Guan Y., 2008, Ecosystem health assessment of lake Nansi wetland. Population. Resources and Environment, 18: 180-184. 